\title{
The Increasing Trend of Black Carbon and Organic Carbon in Jordan During the Period of 2007 to 2018
}

\author{
K. M. Hamasha*† \\ *Department of Physics, Yarmouk University, Jordan \\ †Corresponding author: K.M. Hamasha; khamasha@yu.edu.jo
}

Nat. Env. \& Poll. Tech.

Website: www.neptjournal.com

Received: 22-09-2020

Revised: $01-12-2020$

Accepted: 08-12-2020

Key Words:

Black carbon

Organic carbon

Extinction

Scattering

\begin{abstract}
During the last decades, carbonaceous aerosol extinctions such as black carbon and organic carbon extinctions exhibit an increasing trend across the globe. Measurements of carbonaceous aerosol in Jordan were done using satellite data during the period 2007 to 2018 . These measurements were done in four locations of Jordan - Irbid in the north, Amman and Az-Zarqa in the middle, and Ma'an in the south. Black carbon extinction in Jordan increased slightly (slope $=0.0001$ ) during this period, while organic carbon extinction increased slightly (slope $\left.=(0.7-10) \times 10^{-5}\right)$ in three locations and decreased slightly in one location (Irbid location (slope $\left.=-2 \times 10^{-5}\right)$ ). Organic carbon extinction measurements were greater than black carbon extinction measurements in all locations with varying ratios depending on the location of the measurements. Black carbon and organic carbon scattering measurements have the same behavior as extinction, with larger values in the north and smaller values in the south. Scattering values of organic carbon are larger than black carbon scattering values. Scattering values of organic carbon increased slightly in all locations (slope $=0.0001$ ) while scattering values of black carbon decreased in three locations (Irbid, Amman, and Ma'an) and increased in one location (Az-Zarqa). Column mass density and surface mass concentration measurements show that organic carbon had larger values than black carbon in all locations besides that both organic carbon and black carbon had values decreasing when we go from north to south.
\end{abstract}

\section{INTRODUCTION}

Atmospheric aerosols have a significant impact on regional air pollution as well as on the radiation budget. Atmospheric aerosols directly affect the earth's radiative balance and climate by absorbing and scattering solar and thermal radiation (Myhre et al. 2013). Thus, in contrast to the greenhouse gases which only cause warming, atmospheric aerosols, depending on their properties, can cause either cooling or warming of the atmosphere (IPCC 2018). Aerosols also can indirectly affect the Earth's radiation balance and climate by changing the microphysical properties of clouds and their lifetimes, thereby modifying the precipitation regime (Zhanqing et al. 2017). Aerosols play a major role in atmospheric chemistry and hence affect the concentrations of the other minor atmospheric constituents like ozone (MacKenzie et al. 2011). Furthermore, aerosols have adverse effects on human health, and a strong relationship between aerosol concentration and human mortality and morbidity has been observed (Hime et al. 2018). Aerosols also have adverse effects on environmental quality including visibility (Lung et al. 2016).

Both the aerosol geographical and temporal distributions are very variable due to the short lifetime of particles in conjunction with various, not uniformly distributed sources and different extinction strengths. Additionally, particle transformations during transport as well as removal processes contribute to the observed variability. Hence, it is important to monitor the physical, chemical, and radiative properties of aerosol at a wide range of sites around the globe to build up a comprehensive picture of aerosols and their environmental impacts.

Carbonaceous aerosols are black carbon and organic carbon (McDonald et al. 2015). Black carbon (BC), often called soot, is composed of pure carbon clusters. BC is one of the most important absorbing aerosol species in the atmosphere. Organic carbon (OC) is clustered or aggregated organic molecules.

In Jordan few studies have been conducted to monitor the optical (Hamasha 2010, Hamasha and Arnott 2010, Hamasha et al. 2015) and physical properties of aerosol particles in Jordan (Huessien et al. 2011); still, there is a lack of information about this topic which has persuaded us to initiate this study.

In this study measurements of black carbon mass density, black carbon extinction at $550 \mathrm{~nm}$, black carbon scattering at $550 \mathrm{~nm}$, black carbon surface mass concentration, organic carbon mass density, organic carbon extinction at $550 \mathrm{~nm}$, 
organic carbon scattering at $550 \mathrm{~nm}$, and organic carbon surface mass concentration were recorded using satellite maps at four different sites in Jordan; Irbid in the North, Amman and Az-Zarqa in the middle, and Ma'an in the south for the period $2007-2018$. Satellite maps were produced with the Giovanni online data system, developed and maintained by the NASA GES DISC.

\section{MATERIALS AND METHODS}

Black Carbon (BC) is one of the primary constituent components of atmospheric aerosols. Black carbon aerosols are highly absorbing, and an important factor in radiative forcing, radiative transfer, and pollution.

Organic carbon (OC) may refer to carbon in the atmosphere or ocean and refers to airborne chemical species with a biological origin (Mok et al. 2016) other than methane $\left(\mathrm{CH}_{4}\right)$, carbon monoxide $(\mathrm{CO})$, or carbon dioxide $\left(\mathrm{CO}_{2}\right)$. Atmospheric OC is primarily an aerosol and has applications in pollution and radiative transfer.

This study on BC and OC is conducted in Jordan through measurements of extinction aerosol optical thickness (AOT) at $550 \mathrm{~nm}$, scattering AOT at $550 \mathrm{~nm}$, column mass density, and surface mass concentrations. $\mathrm{BC}$ and $\mathrm{OC}$ data was recorded from satellite using Giovanni online data system, developed and maintained by the NASA GES DISC during the period from 2007 to 2018 at four locations in Jordan.

Satellite remote sensing and model data play an important role in research and applications of tropical meteorology and climatology. Since the first weather satellite was launched by NASA in 1960, a large collection of NASA's Earth science data is freely available to the research and application communities around the world, significantly improving our overall understanding of the Earth system and environment. Established in the mid-1980s, the NASA Goddard Earth Sciences Data and Information Services Center (GES DISC) is a data archive center for multidisciplinary, satellite, and model assimilation data products (Liu et al. 2020). GES DISC hosts several important NASA satellite missions for tropical meteorology and climatology. Over the years, GES DISC has developed data services to facilitate data discovery, access, distribution, analysis, and visualization, including Giovanni. Giovanni is an online analysis and visualization tool without the need to download data and software (Acker \& Leptoukh 2007). Using the Giovanni user interface, it is possible to easily find and display selected data on various types of plots. At the top of the interface are menus for the various kinds of visualizations available in Giovanni. The default visualization is a time-averaged map. The time-averaged map shows data values for each grid cell within the user-specified area, averaged over the user-specified time range as a map layer. Fill values do not contribute to the time average value. The generated map can be zoomed in and panned. Plot options include setting minimum and maximum values for the color scale and in some cases selecting other palettes.

The social and economic development in Jordan has been accompanied by an increase in the consumption of oil for different needs, including residential, commercial, industrial, transportation, and power generation. Combustion of oil and other fossil fuel is recognized as a major source of air pollution in urban areas. Several airborne substances can remain in the atmosphere for weeks, and travel over hundreds of kilometers, making air pollution a global problem. Measurements of black carbon light absorption coefficients $\left(\mathrm{B}_{\mathrm{abs}}\right)$ using the photoacoustic instrument at the wavelength of $870 \mathrm{~nm}$ in different locations of Jordan show that $\mathrm{B}_{\mathrm{abs}}$ is higher for the locations in the city centers than the locations in the industrial centers during summer 2007 (Hamasha et al. 2010). Low black carbon concentrations in the vicinity of industrial zones are attributed to the efficiency of tall stacks in reducing ground-level concentrations of emitted substances.

The study locations in Jordan (maps) are Irbid, Amman, Az-Zarqa, and Ma' an (Fig. 1). Irbid city ( $32^{\circ} 33^{\prime}$ N, 35 $51^{\circ}$ ' $\mathrm{E}$ ) is situated in the north of Jordan, in a fertile plateau, with an average elevation of $620 \mathrm{~m}$. The city has a population of about 2 Million. Irbid is located about $70 \mathrm{~km}$ north of the capital city Amman and approximately $20 \mathrm{~km}$ south of the Syrian border. It has a hot-summer Mediterranean climate. Summers are hot on days with warm nights while winters are cool and wet with two snowy days on average. Rain averages about $500 \mathrm{~mm}$ a year.

Amman ( $\left.31^{\circ} 57^{\prime} \mathrm{N}, 35^{\circ} 56^{\prime} \mathrm{E}\right)$ is the capital and most populous city of Jordan, situated in north-central Jordan. The city has a population of about 4.3 Million, and elevation ranged between $700 \mathrm{~m}-1100 \mathrm{~m}$. Originally, the city had been built on seven hills. Amman's position on the mountains near the Mediterranean climate zone places it under the semi-arid climate classification. Rain averages about $300 \mathrm{~mm}$ a year and periodic droughts are common, where most rain falls between October and April.

Az-Zarqa $\left(32^{\circ} 5^{\prime} \mathrm{N}, 36^{\circ} 6^{\prime} \mathrm{E}\right)$ is located on the Az-Zarqa River basin in northeast Jordan. The city is situated $24 \mathrm{~km}$ northeast of Amman. Az-Zarqa has a cold semi-arid climate. The average annual temperature is $17.4^{\circ} \mathrm{C}$, and around $182 \mathrm{~mm}$ of precipitation falls annually, mostly in the winter months.

Ma' an $\left(30^{\circ} 11^{\prime} \mathrm{N}, 35^{\circ} 44^{\prime} \mathrm{E}\right)$ is a city in southern Jordan, $218 \mathrm{~km}$ southwest of the capital Amman. Ma' an has a cold desert climate, with hot summers and mild to cold winters due to its high altitude (above 1000 meters). Rainfall is extremely rare with an average of $44 \mathrm{~mm}$ a year only. 


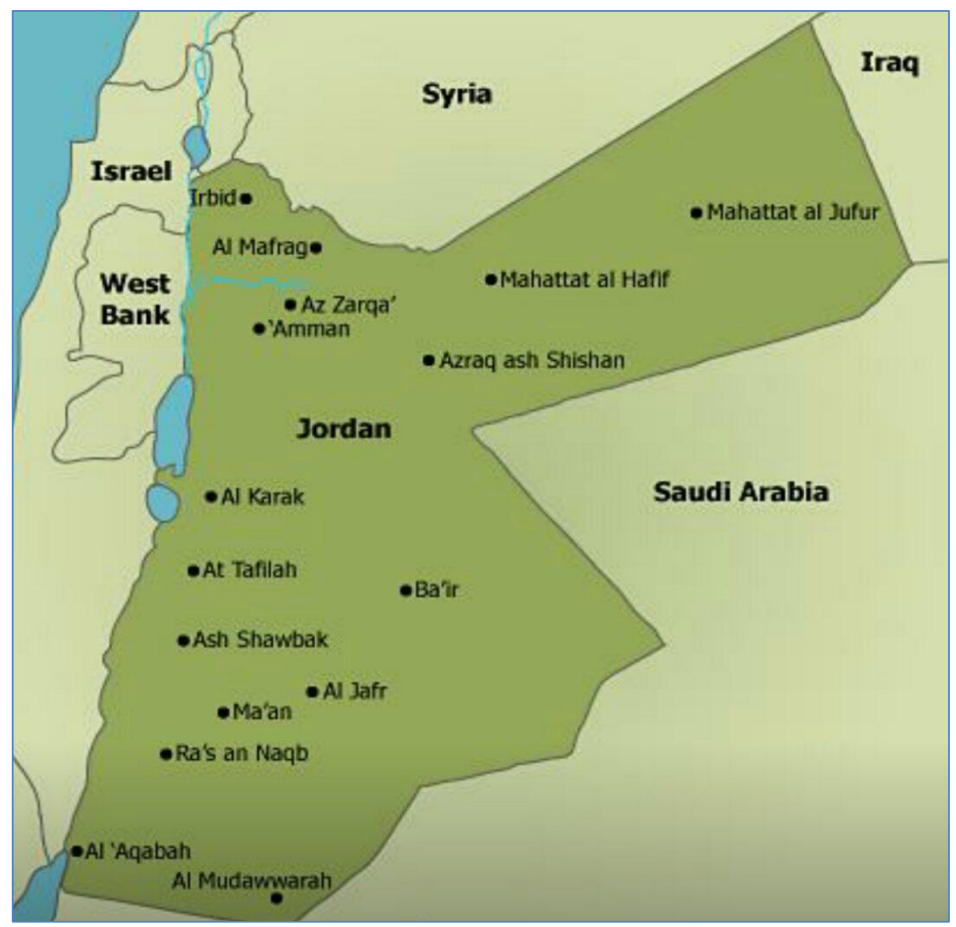

Fig. 1: Map of Jordan.

\section{RESULTS AND DISCUSSION}

\section{Black Carbon Extinction AOT at 550 nm}

Black carbon extinction AOT at $550 \mathrm{~nm}$ data was collected from Giovanni online data system satellite maps at four locations from Jordan - Irbid in the north, Amman and AzZarqa in the middle, and Ma' an in the south.
Fig. 2 shows yearly averaged BC extinction AOT at 550 $\mathrm{nm}$. BC extinction values for all data, from greatest, were in Irbid, Amman, Az-Zarqa, and then Ma'an. Irbid and Amman had very close data, while Ma' an had faraway data from them. Ma' an has a very large area most of it desert with a low population compared with the other cities. Irbid has the largest $\mathrm{BC}$ extinction because of the many sources of $\mathrm{BC}$ in

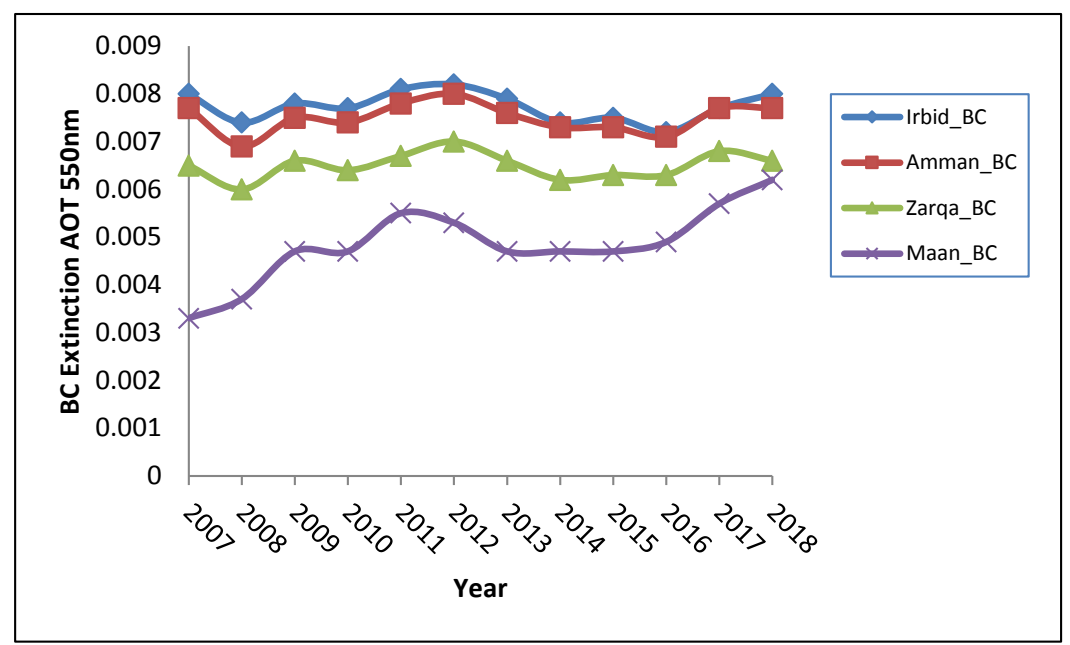

Fig. 2: Average black carbon extinction AOT at $550 \mathrm{~nm}$ for the period from 2007 to 2018 in Irbid, Amman, Az-Zarqa, and Ma'an locations. 
the city and its location close to the border of Syria and Israel. Irbid, Amman, and Az-Zarqa had the largest average value of BC extinction in 2012, while Ma' an had the largest average value of BC extinction in 2018. Data for Irbid, Amman, and Az-Zarqa have the same behavior up and down. For Ma'an, BC extinction goes up from 2007 to 2011 then went down in 2013 and became stable in 2015 then kept going up till 2018. The reason for the increase in black carbon levels in 2012 is due to the Syrian civil war, as Syria is adjacent to the northern Jordanian border and close to central Jordan.

\section{Organic Carbon Extinction AOT at $550 \mathrm{~nm}$}

Organic carbon extinction AOT at $550 \mathrm{~nm}$ data was collected from Giovanni online data system satellite maps at four locations from Jordan - Irbid in the north, Amman in the and Az-Zarqa in the middle, and Ma' an in the south.
Fig. 3 shows yearly averaged OC extinction AOT at 550 $\mathrm{nm}$. For all data, Irbid had the largest OC extinction values and Ma' an had the lowest values. Ma' an has a very large area most of it desert with a low population compared with the other cities. Irbid has the largest OC extinction because of the many sources of OC in the city. Agricultural pollutants and livestock are the most important sources of organic carbon, which are abundant in an agricultural region such as Irbid.

All of the cities had the largest average value of OC extinction in 2017, and the lowest values of OC extinction in 2008. Data for Irbid, Amman, Az-Zarqa, and Ma' an have the same behavior fluctuations up and down.

\section{Black Carbon and Organic Carbon Extinction AOT at $550 \mathrm{~nm}$}

Figs. 4-7 show the comparison of extinction AOT at 550

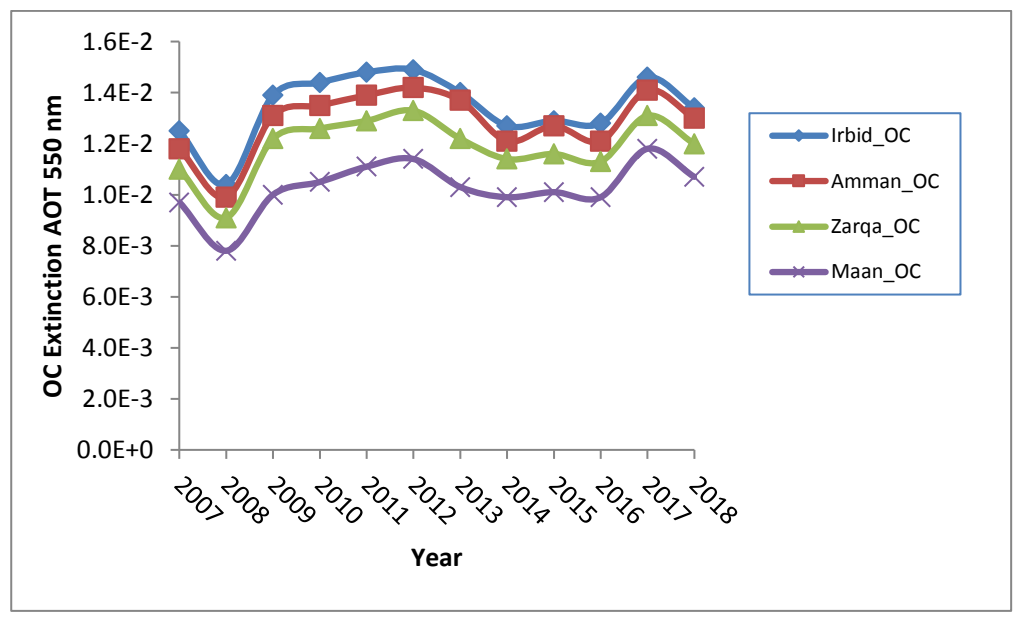

Fig. 3: Average organic carbon extinction AOT at $550 \mathrm{~nm}$ for the period from 2007 to 2018 in Irbid, Amman, Az-Zarqa, and Ma'an locations.

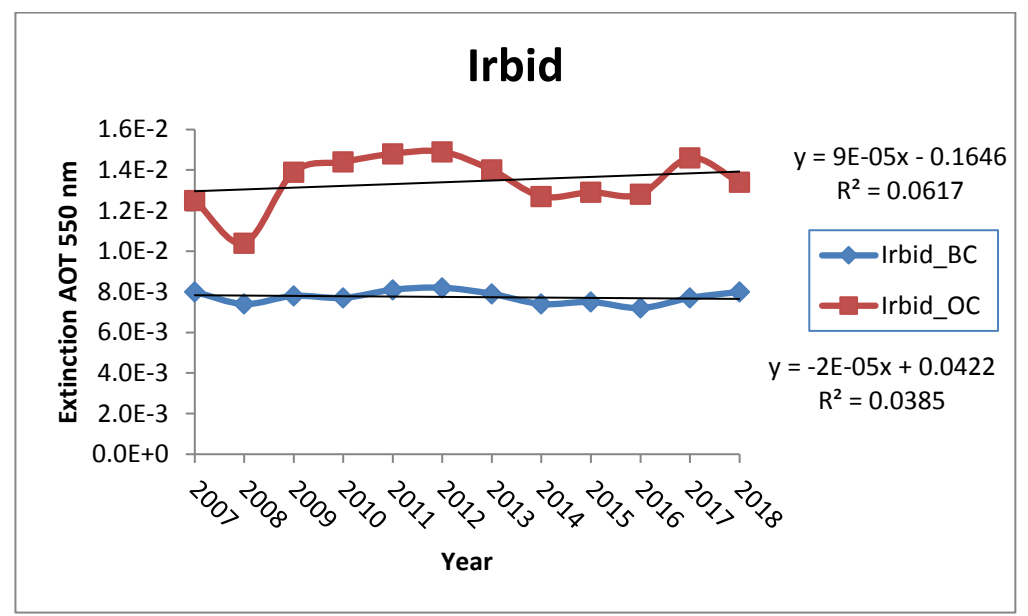

Fig. 4: Average extinction AOT at $550 \mathrm{~nm}$ for black carbon and organic carbon during the period from 2007 to 2018 in Irbid city. 


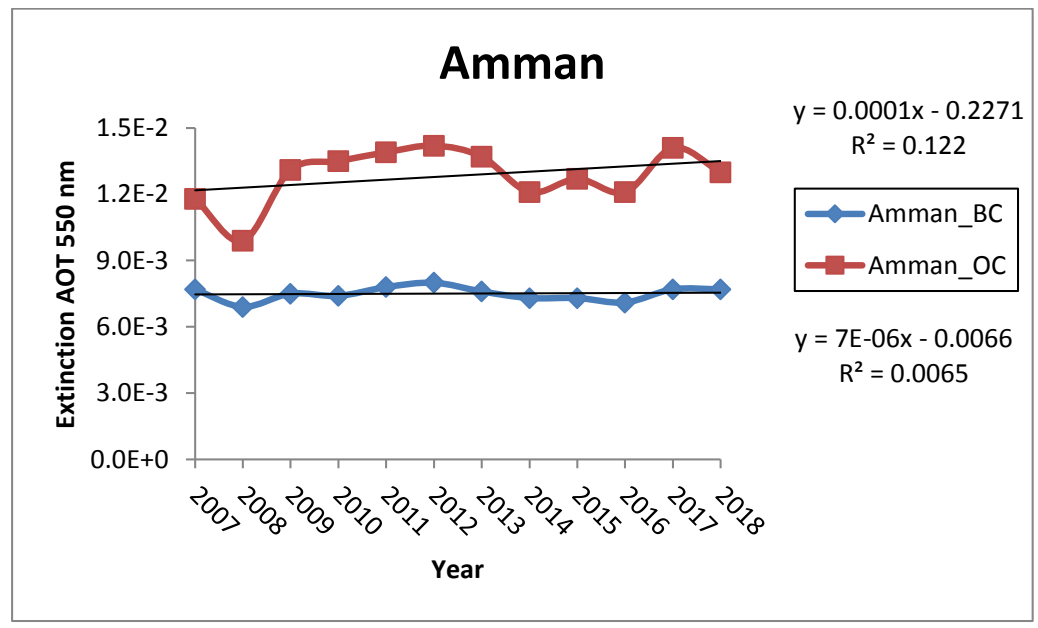

Fig. 5: Average extinction AOT at $550 \mathrm{~nm}$ for black carbon and organic carbon during the period from 2007 to 2018 in Amman city.

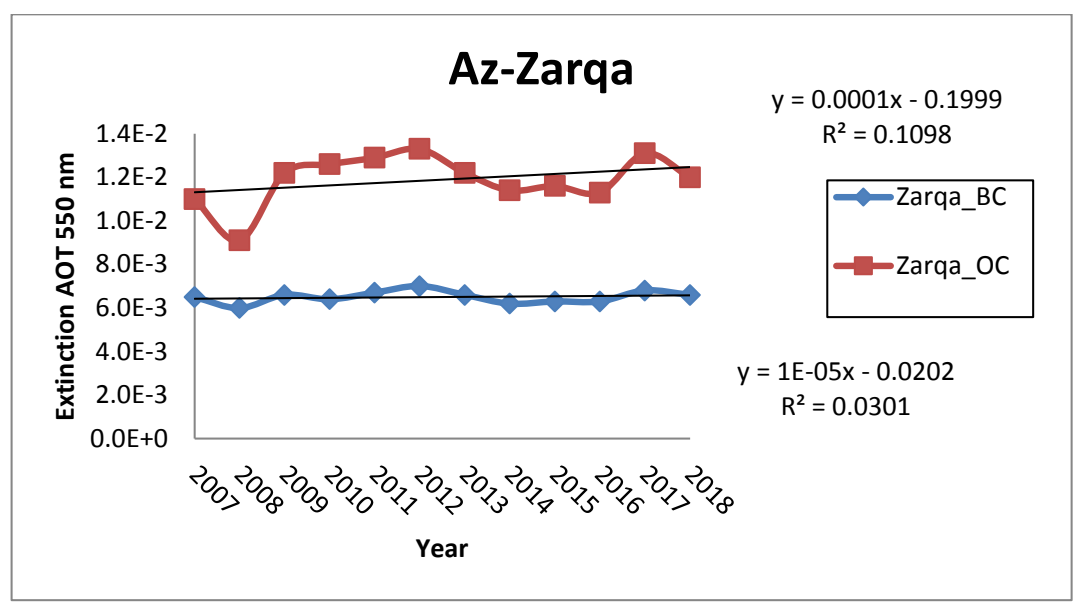

Fig. 6: Average extinction AOT at $550 \mathrm{~nm}$ for black carbon and organic carbon during the period from 2007 to 2018 in Az-Zarqa city.

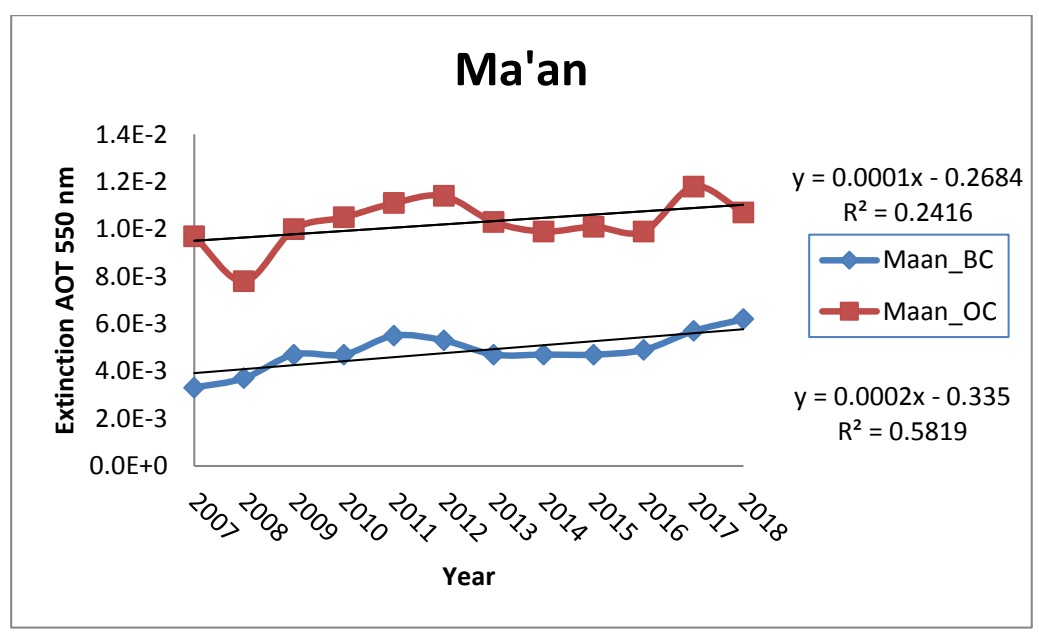

Fig. 7: Average extinction AOT at $550 \mathrm{~nm}$ for black carbon and organic carbon during the period from 2007 to 2018 in Ma' an city. 
$\mathrm{nm}$ between $\mathrm{BC}$ and $\mathrm{OC}$ for the four locations during the period from 2007 to 2018. From Fig 4-7, for the yearly average extinction, $\mathrm{OC}$ is greater than $\mathrm{BC}$ in all four cities. OC extinction in Jordan increased slightly (slope $=0.0001)$ during this period, while $\mathrm{BC}$ extinction increased slightly (slope $\left.=(0.7-10) \times 10^{-5}\right)$ in three locations and decreased slightly in one location (Irbid location (slope $\left.=-2 \times 10^{-5}\right)$ ).

Figs. 8-11 show the correlations between the yearly average extinction values of $\mathrm{BC}$ and $\mathrm{OC}$ in four cities. For Irbid city, the yearly average extinction value of $\mathrm{OC}$ is about
2.5 times that of BC. For Amman city, the yearly average extinction value of $\mathrm{OC}$ is about 3 times that of $\mathrm{BC}$, and for Az-Zarqa city, the yearly average extinction value of OC is about 3.5 times that of $\mathrm{BC}$. While that for Ma' an city is almost the same.

\section{Black Carbon Scattering AOT at $550 \mathrm{~nm}$}

Black carbon scattering AOT at $550 \mathrm{~nm}$ data was collected from Giovanni's online data system satellite maps at four locations from Jordan - Irbid in the north, Amman and Az-

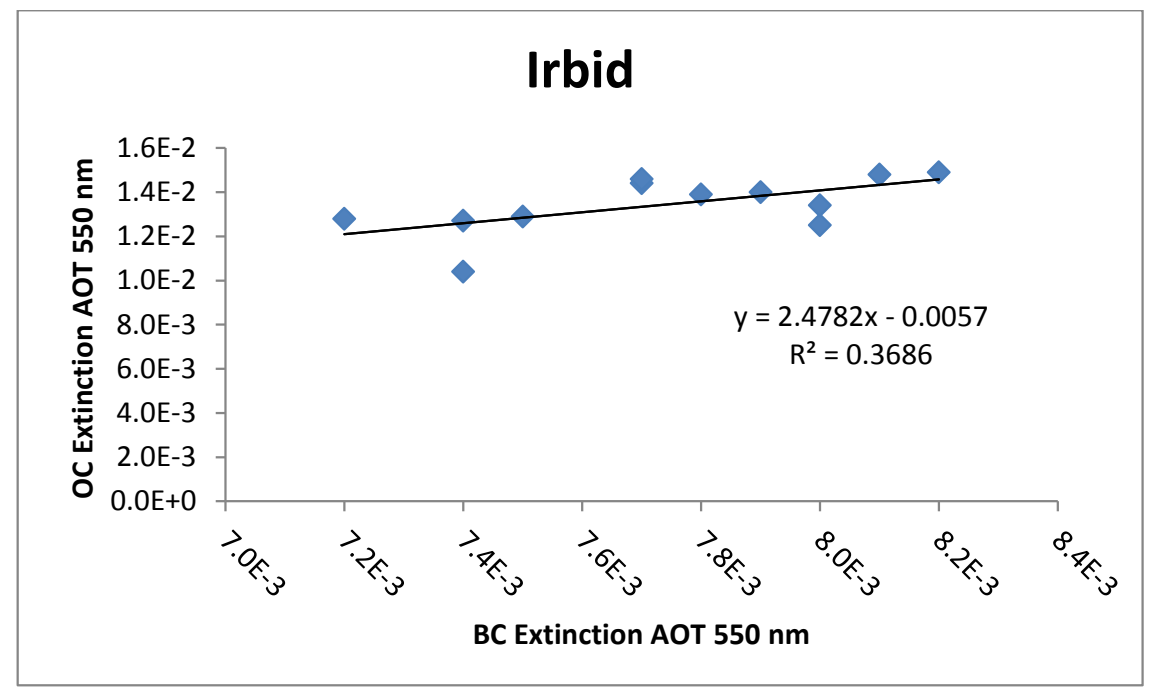

Fig. 8: Correlation between yearly average extinction value of black carbon and organic carbon in Irbid city.

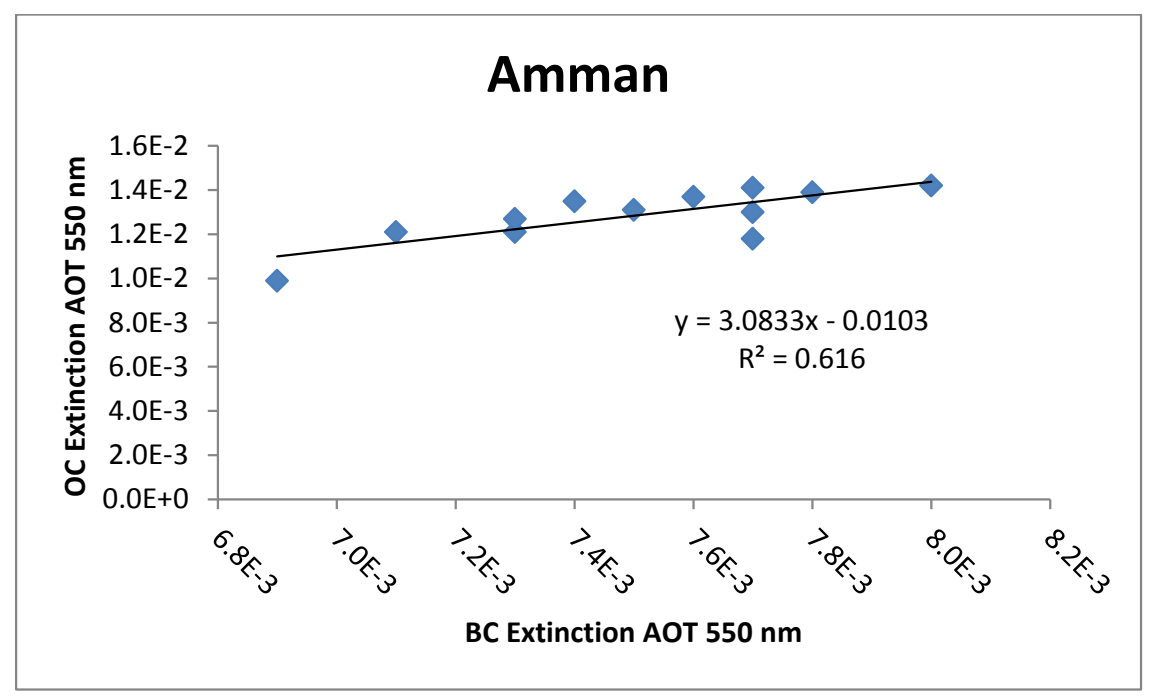

Fig. 9: Correlation between yearly average extinction value of black carbon and organic carbon in Amman city. 


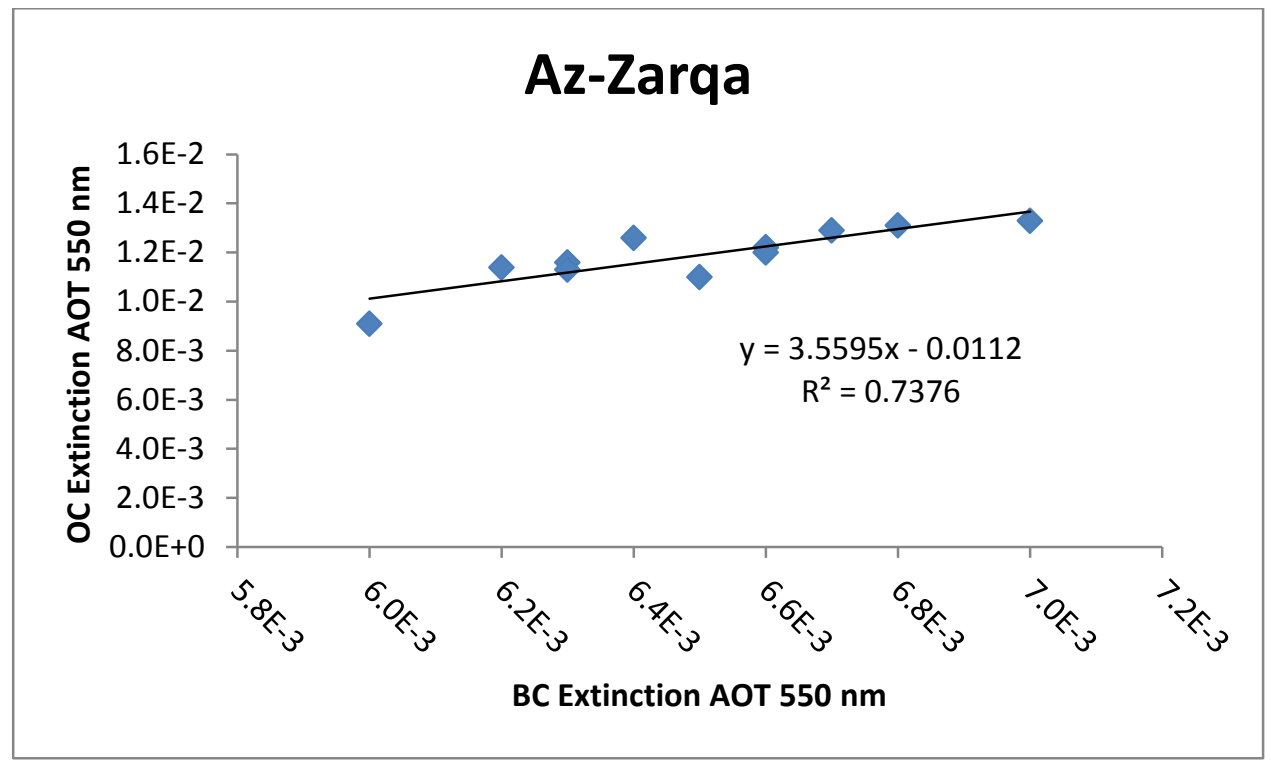

Fig. 10: Correlation between yearly average extinction value of black carbon and organic carbon in Az-Zarqa city.

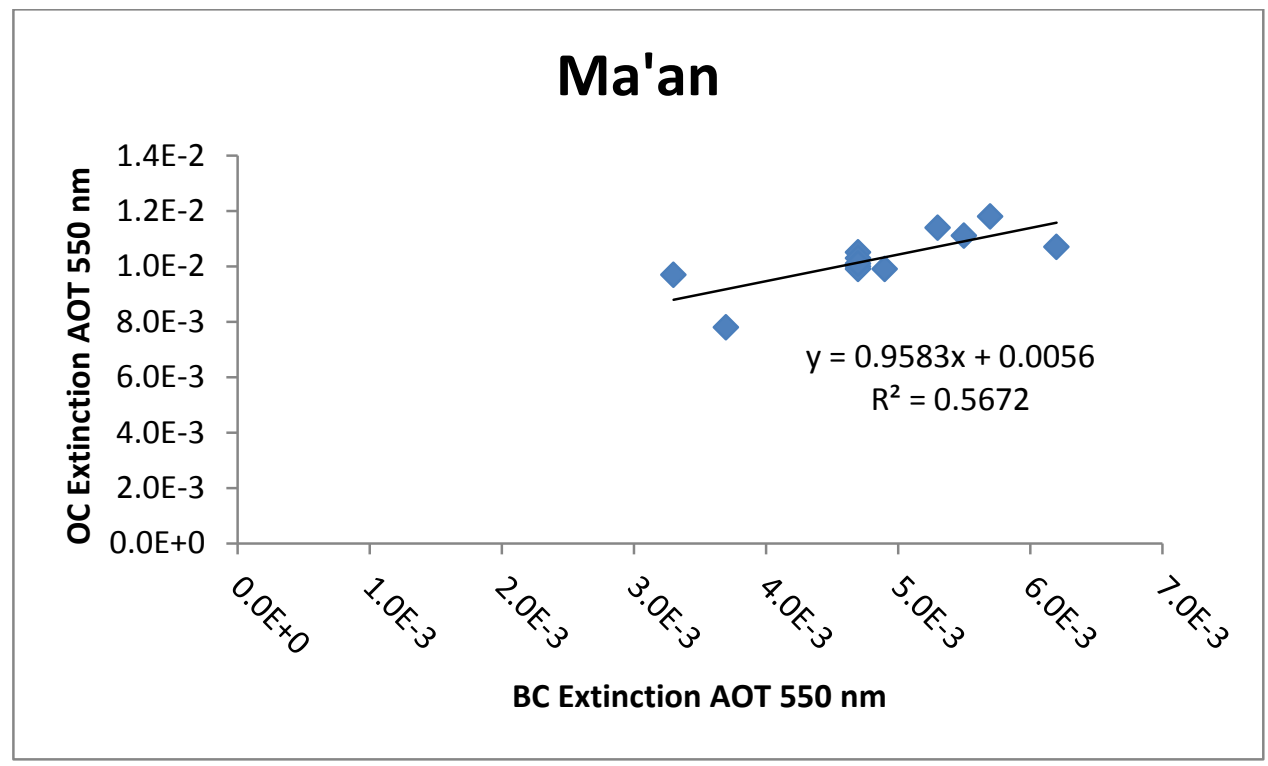

Fig. 11: Correlation between yearly average extinction value of black carbon and organic carbon in Ma'an city.

Zarqa in the middle, and Ma' an in the south. Fig. 12 shows the yearly average $\mathrm{BC}$ scattering AOT at $550 \mathrm{~nm}$. For all data, Irbid had the greatest BC scattering values than Amman and Az-Zarqa, while Ma' an had the lowest value. Data were very close in Irbid and Amman. Ma' an has a very large area most of it desert with a low population compared with the other cities. Irbid has the largest BC scattering because of the many sources of $\mathrm{BC}$ in the city and its location close to the border of Syria and Israel.
Irbid's, Amman's, and Az-Zarqa's BC scattering values were almost constant, while Ma' an had a more fluctuating BC scattering, and had a maximum value in 2017.

\section{Organic Carbon Scattering AOT at $550 \mathrm{~nm}$}

Fig. 13 shows the yearly averaged OC scattering AOT at 550 $\mathrm{nm}$. For all data, Irbid had the greatest OC scattering values than Amman and Az-Zarqa, while Ma'an had the lowest 


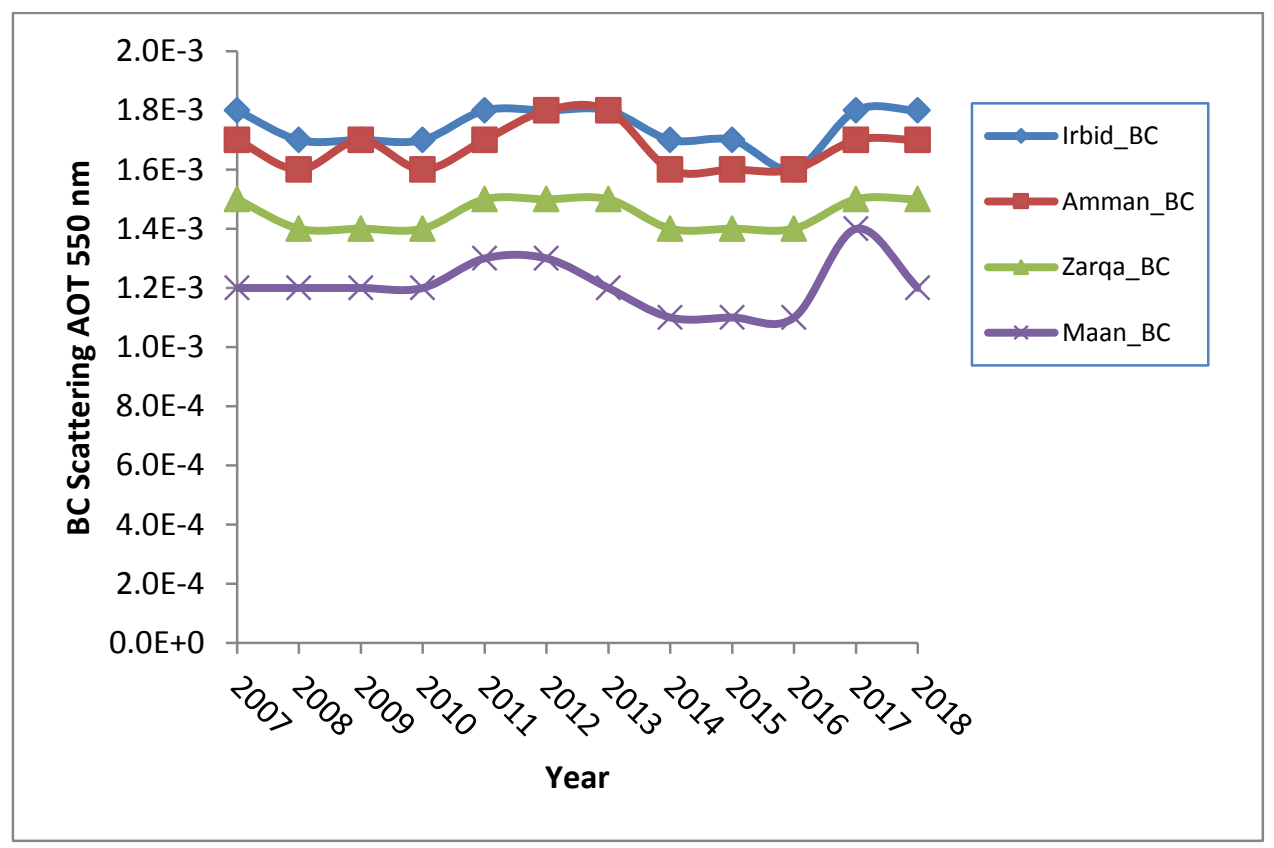

Fig. 12: Average black carbon scattering AOT at $550 \mathrm{~nm}$ for the period from 2007 to 2018 in Irbid, Amman, Az-Zarqa, and Ma'an locations.

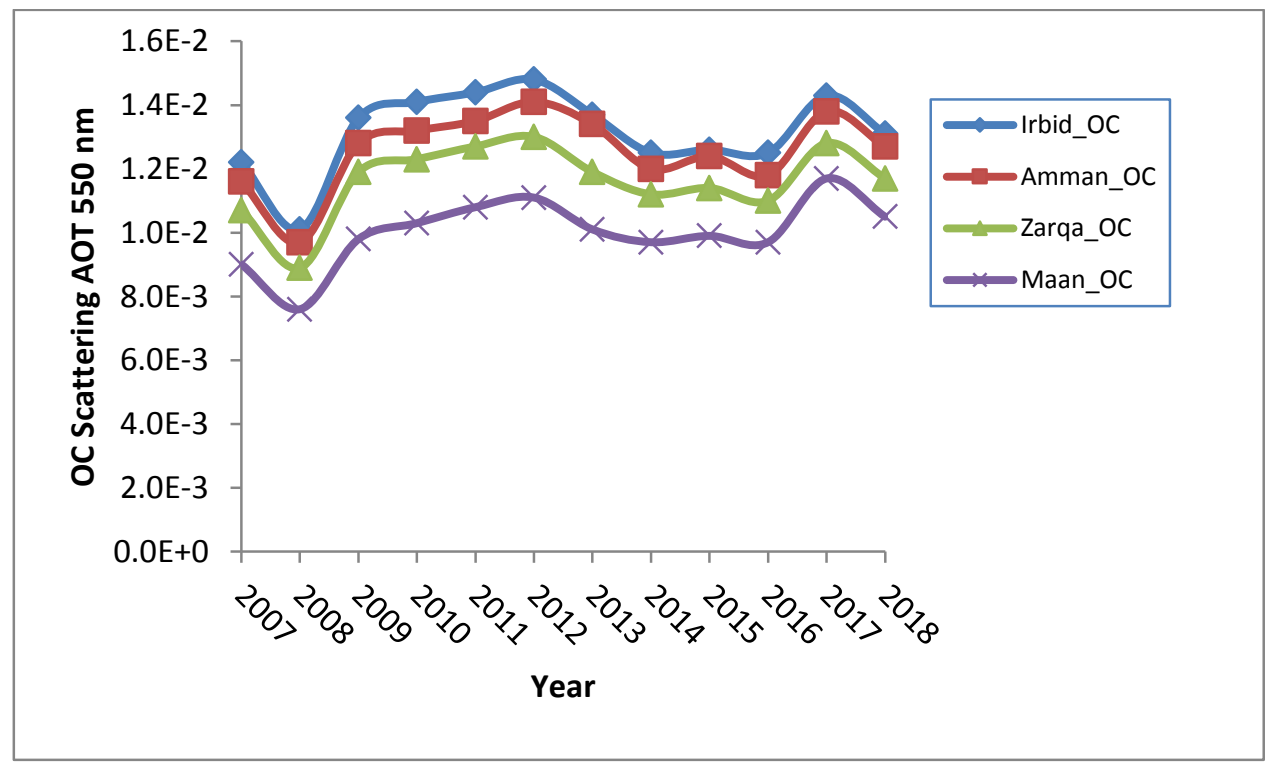

Fig. 13: Average organic carbon scattering AOT at $550 \mathrm{~nm}$ for the period from 2007 to 2018 in four locations from Jordan.

value. Ma'an has a very large area most of it desert with a low population compared with the other cities. Irbid has the largest OC scattering because of the many sources of OC in the city and its location close to the border of Syria and Israel.

All of the cities had the largest average value of OC scattering in 2017, and the lowest values of OC scattering in 2008. Data for Irbid, Amman, Az-Zarqa, and Ma' an show the same behavior fluctuations up and down.

$\mathrm{BC}$ and $\mathrm{OC}$ scattering measurements have the same behavior as extinction with larger values in the north and smaller values in the south. Scattering values of OC are larger than that of $\mathrm{BC}$ 


\section{Black Carbon and Organic Carbon Scattering AOT at $550 \mathrm{~nm}$}

Scattering values of OC increased slightly in all locations (slope $=0.0001$ ) while scattering for BC decreased in three locations (Irbid, Amman, and Ma'an) and increased in the Az-Zarqa location (Figs. 14-17).

Comparison of scattering AOT at $550 \mathrm{~nm}$ between $\mathrm{BC}$ and $\mathrm{OC}$ for the four locations during the period from 2007 to 2018 shows that values of the yearly average scattering of OC are greater than that of BC in all four cities. Figs. 18-21 show the correlations between the yearly average scattering values of $\mathrm{BC}$ and $\mathrm{OC}$ in four cities. For Irbid city, the yearly average scattering value of $\mathrm{OC}$ is about 8.6 times that of $\mathrm{BC}$. For Amman city, the yearly average scattering value of $\mathrm{OC}$ is about 9.8 times that of BC, and for Az-Zarqa city, the yearly average scattering value of $\mathrm{OC}$ is about 10.1 times that of $\mathrm{BC}$. While in Ma' an city, the yearly average scattering value for $\mathrm{OC}$ is about 6.7 times that for $\mathrm{BC}$.

\section{Black Carbon Column Mass Density}

Black carbon column mass density has values between $3 \times$ $10^{-7} \mathrm{~kg} \cdot \mathrm{m}^{-2}$ and $8.5 \times 10^{-7} \mathrm{~kg} \cdot \mathrm{m}^{-2}$ (Fig. 22). Irbid city has an average value of BC mass concentration of $7.8 \times 10^{-7} \mathrm{~kg} \cdot \mathrm{m}^{-2}$, while Amman, Az-Zarqa, and Ma' an have values of $6.7 \times 10^{-7}$

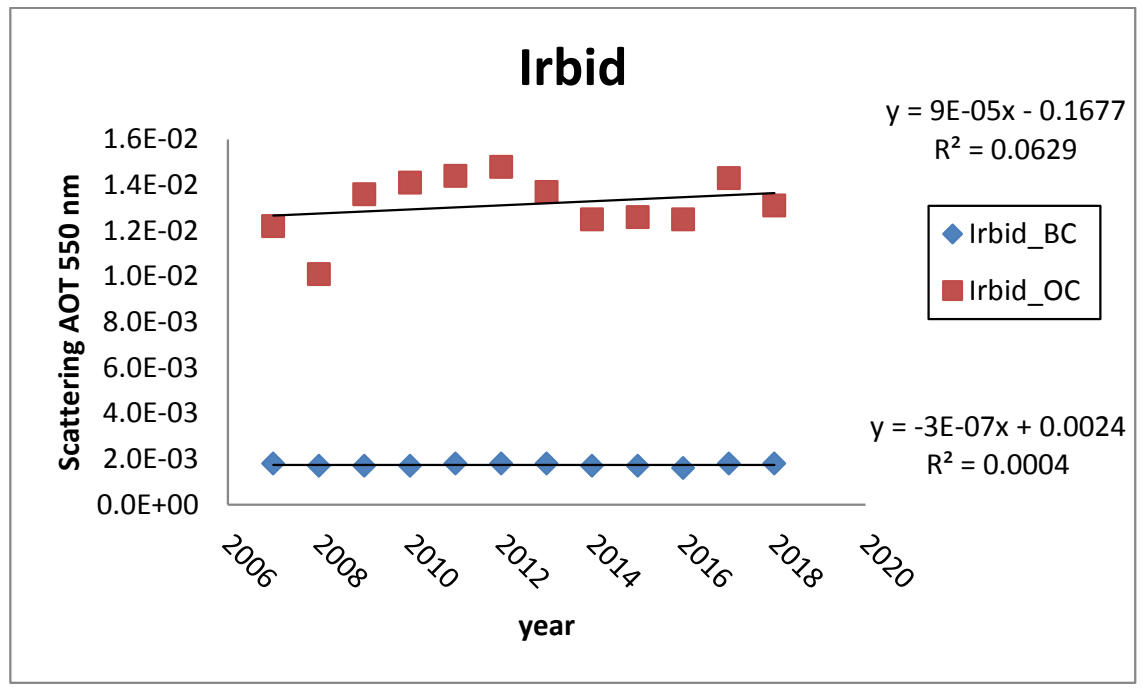

Fig. 14: Average scattering AOT at $550 \mathrm{~nm}$ for black carbon and organic carbon during the period from 2007 to 2018 in Irbid city.

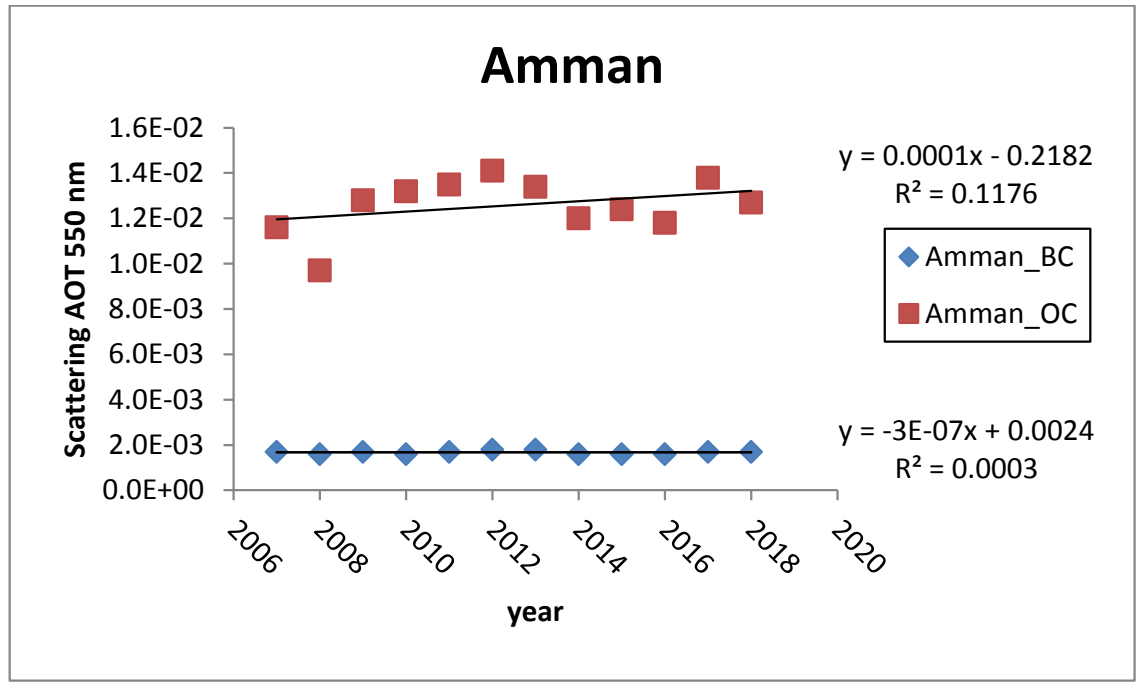

Fig. 15: Average scattering AOT at $550 \mathrm{~nm}$ for black carbon and organic carbon during the period from 2007 to 2018 in Amman city. 


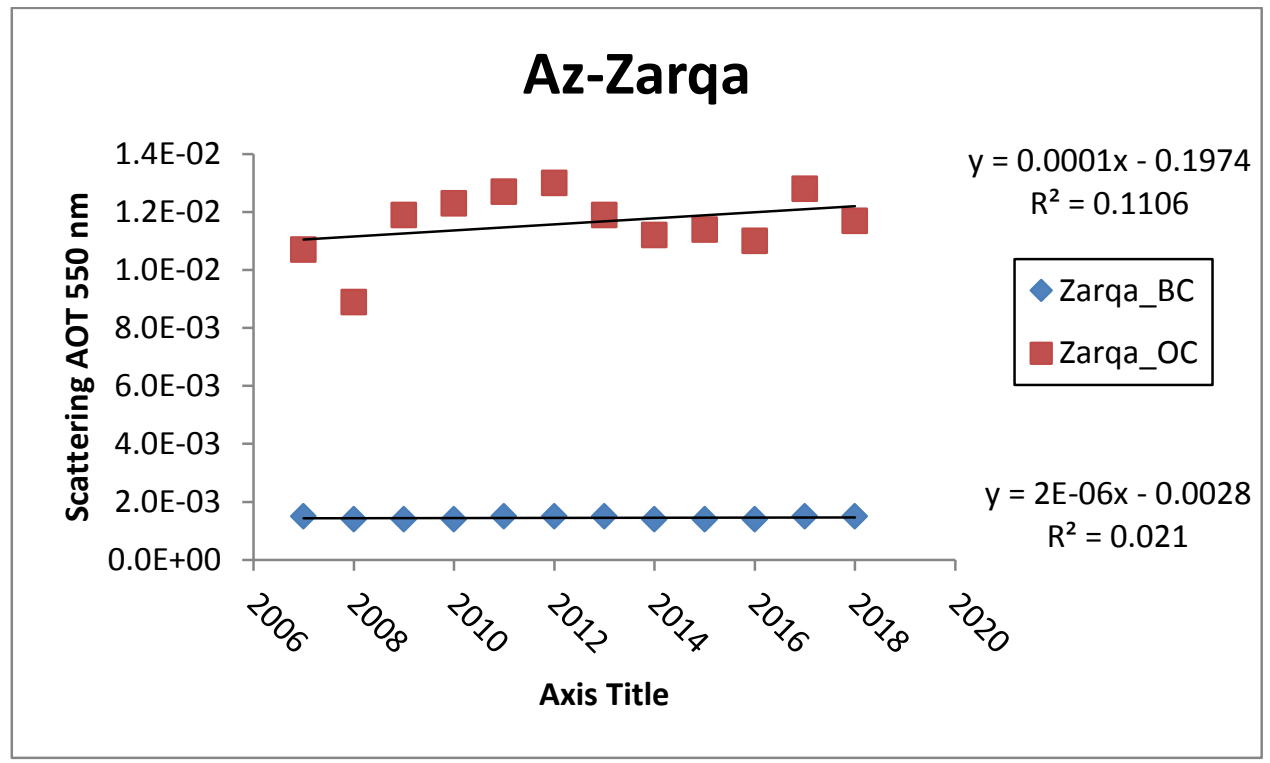

Fig. 16: Average scattering AOT at $550 \mathrm{~nm}$ for black carbon and organic carbon during the period from 2007 to 2018 in Az-Zarqa city.

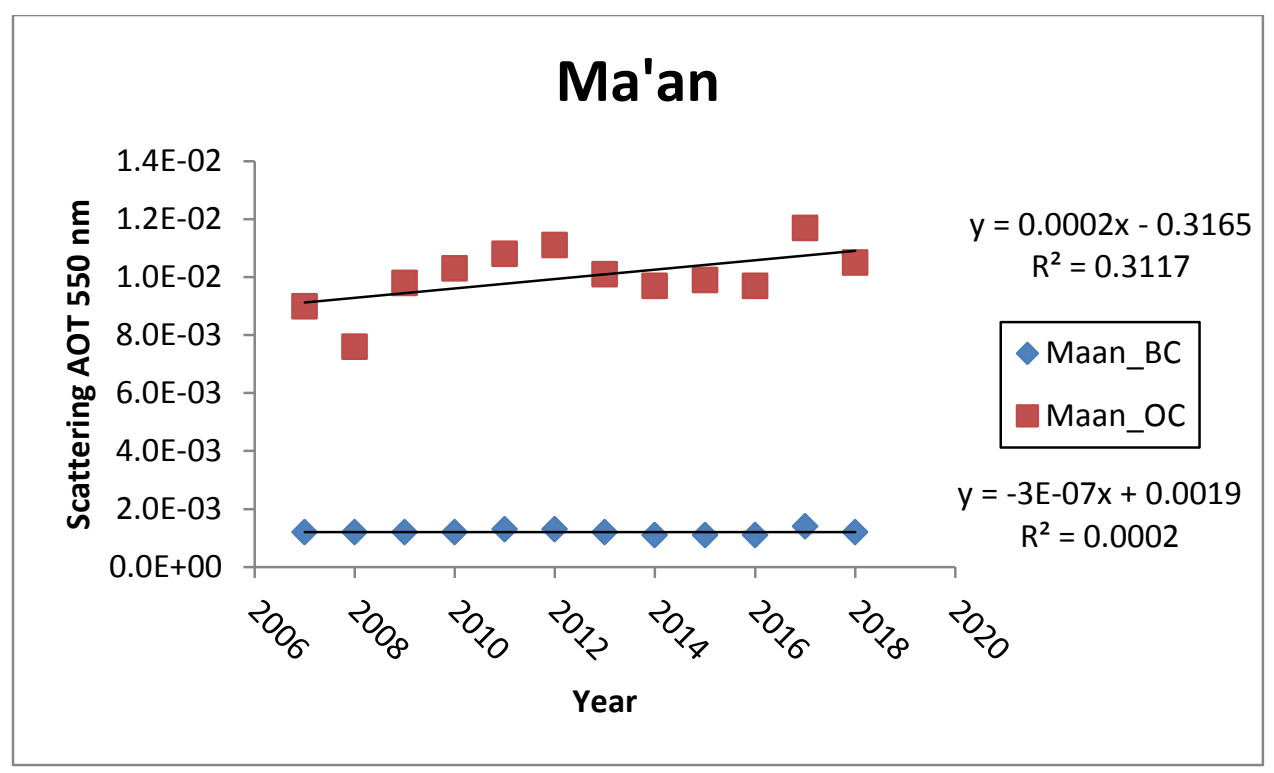

Fig. 17: Average scattering AOT at $550 \mathrm{~nm}$ for black carbon and organic carbon during the period from 2007 to 2018 in Ma'an city.

$\mathrm{kg} \cdot \mathrm{m}^{-2}, 5.1 \times 10^{-7} \mathrm{~kg} \cdot \mathrm{m}^{-2}$, and $5.1 \times 10^{-7} \mathrm{~kg} \cdot \mathrm{m}^{-2}$ respectively.

OC column mass density has values between $18.5 \times$ $10^{-7} \mathrm{~kg} \cdot \mathrm{m}^{-2}$ and $32.4 \times 10^{-7} \mathrm{~kg} \cdot \mathrm{m}^{-2}$ (Fig. 23). Irbid city has an average value of $\mathrm{BC}$ mass concentration of $28.8 \times 10^{-7}$ $\mathrm{kg} . \mathrm{m}^{-2}$, while Amman, Az-Zarqa, and Ma' an have values of $28.1 \times 10^{-7} \mathrm{~kg} \cdot \mathrm{m}^{-2}, 25.3 \times 10^{-7} \mathrm{~kg} \cdot \mathrm{m}^{-2}, 23.2 \times 10^{-7} \mathrm{~kg} \cdot \mathrm{m}^{-2}$ respectively.

Figs. 24-27 show the correlation between BC column mass density and OC column mass density. OC column mass density in all sites has a greater value than $\mathrm{BC}$ column mass density. In Irbid and Amman, OC mass density is about 6 times BC mass density, while in Az-Zarqa, OC mass density is about 7 times that of $\mathrm{BC}$ mass density. Finally, in Ma'an, $\mathrm{OC}$ mass density is about 1.5 times that of $\mathrm{BC}$ mass density

Black Carbon and Organic Carbon Surface Mass Concentration 


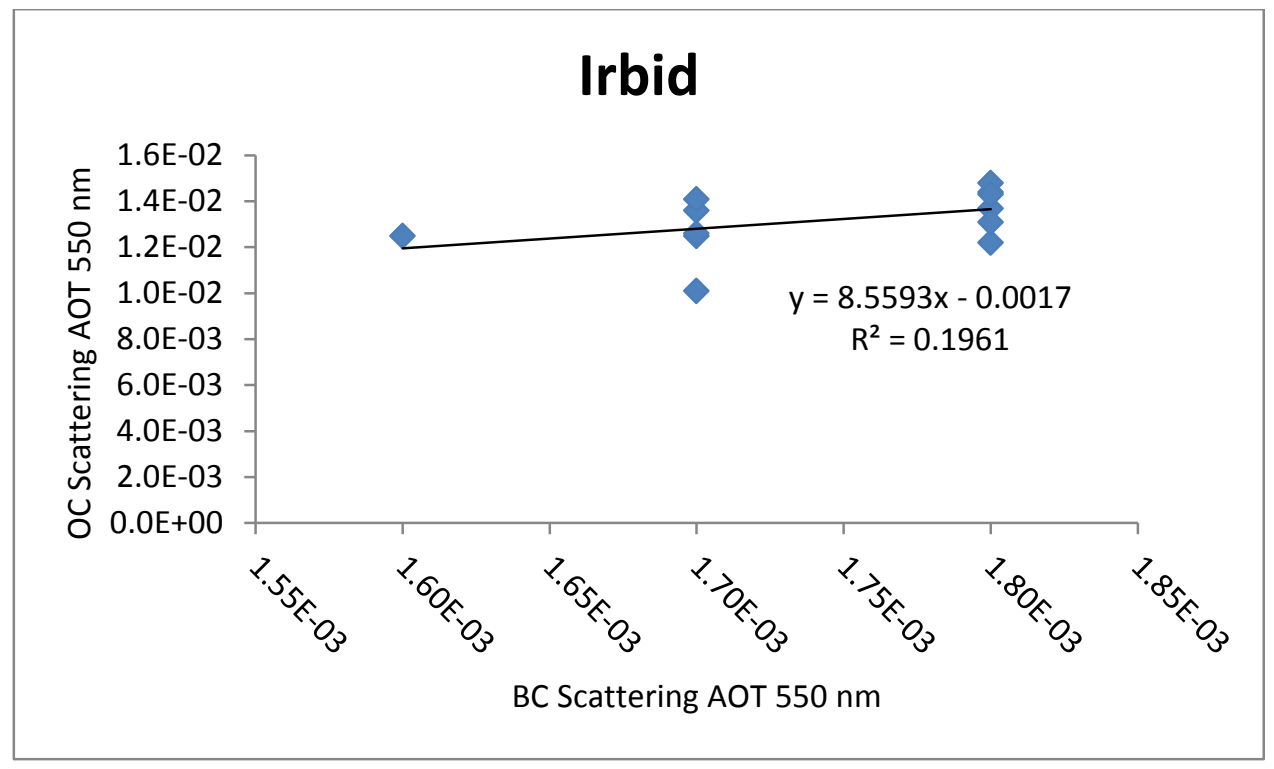

Fig. 18: Correlation between yearly average scattering value of black carbon and organic carbon in Irbid city.

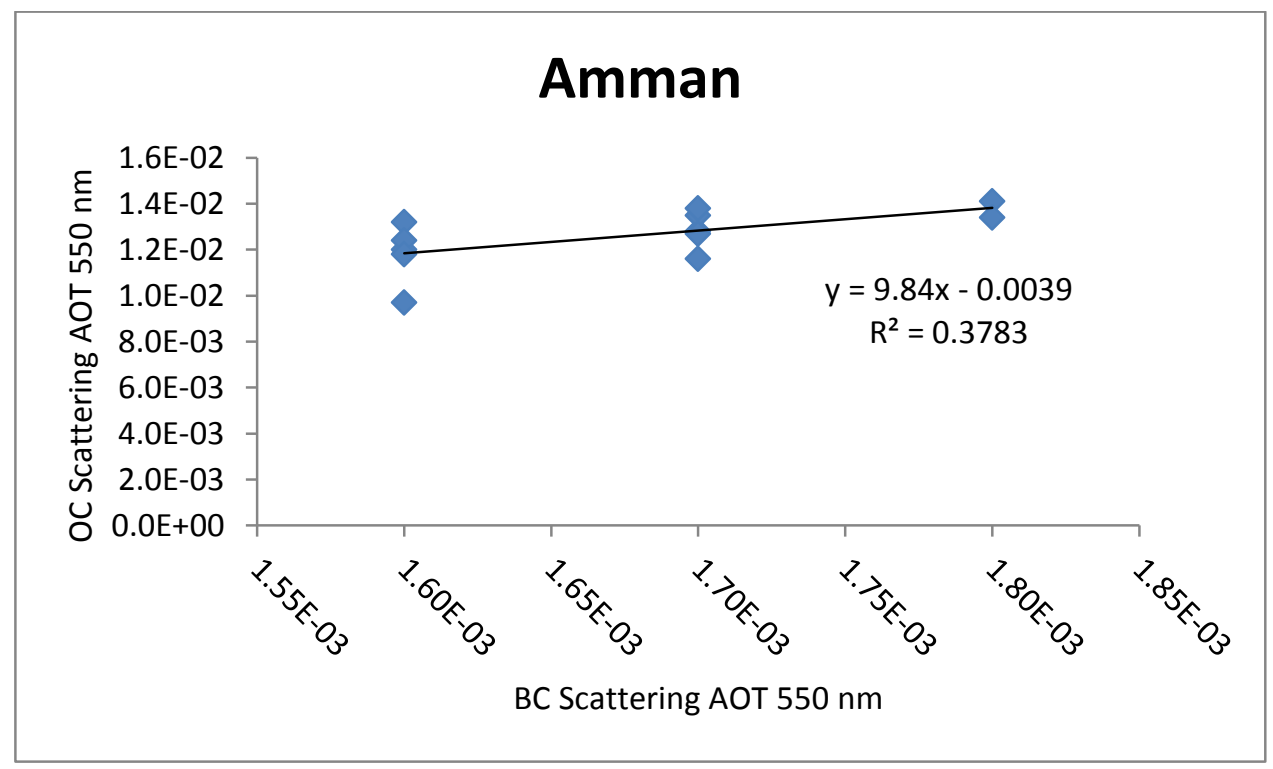

Fig. 19: Correlation between yearly average scattering value of black carbon and organic carbon in Amman city.

BC mass concentration has values between $1.5 \times 10^{-4} \mathrm{mg} \cdot \mathrm{m}^{-}$ ${ }^{3}$ and $6 \times 10^{-4} \mathrm{mg} \cdot \mathrm{m}^{-3}$ (Fig. 28). Irbid city has an average value of $\mathrm{BC}$ mass concentration of $5.6 \times 10^{-4} \mathrm{mg} \cdot \mathrm{m}^{-3}$, while Amman, Az-Zarqa, and Ma'an have values of $5.1 \times 10^{-4}$ mg. $\mathrm{m}^{-3}, 3.6 \times 10^{-4} \mathrm{mg} \cdot \mathrm{m}^{-3}, 1.6 \times 10^{-4} \mathrm{mg} \cdot \mathrm{m}^{-3}$ respectively.

OC mass concentration has values between $4.6 \times 10^{-4}$ mg. $\mathrm{m}^{-3}$ and $12.3 \times 10^{-4} \mathrm{mg} . \mathrm{m}^{-3}$ (Fig. 29). Irbid city has an average value of $\mathrm{BC}$ mass concentration of $11.5 \times 10^{-4} \mathrm{mg} \cdot \mathrm{m}^{-3}$, while Amman, Az-Zarqa, and Ma' an have values of $10.4 \times 10^{-4}$ mg.m ${ }^{-3}, 10.0 \times 10^{-4} \mathrm{mg} \cdot \mathrm{m}^{-3}, 5.2 \times 10^{-4} \mathrm{mg} \cdot \mathrm{m}^{-3}$ respectively.

Figs. 30-33 show the correlation between BC mass concentration and $\mathrm{OC}$ mass concentration. $\mathrm{OC}$ mass concentration in all sites has a greater value than $\mathrm{BC}$ mass concentration. In Irbid city, OC mass concentration is about 3 times BC mass concentration, while in Amman, Az-Zarqa, and Ma'an it is about 2 times BC mass concentration. 


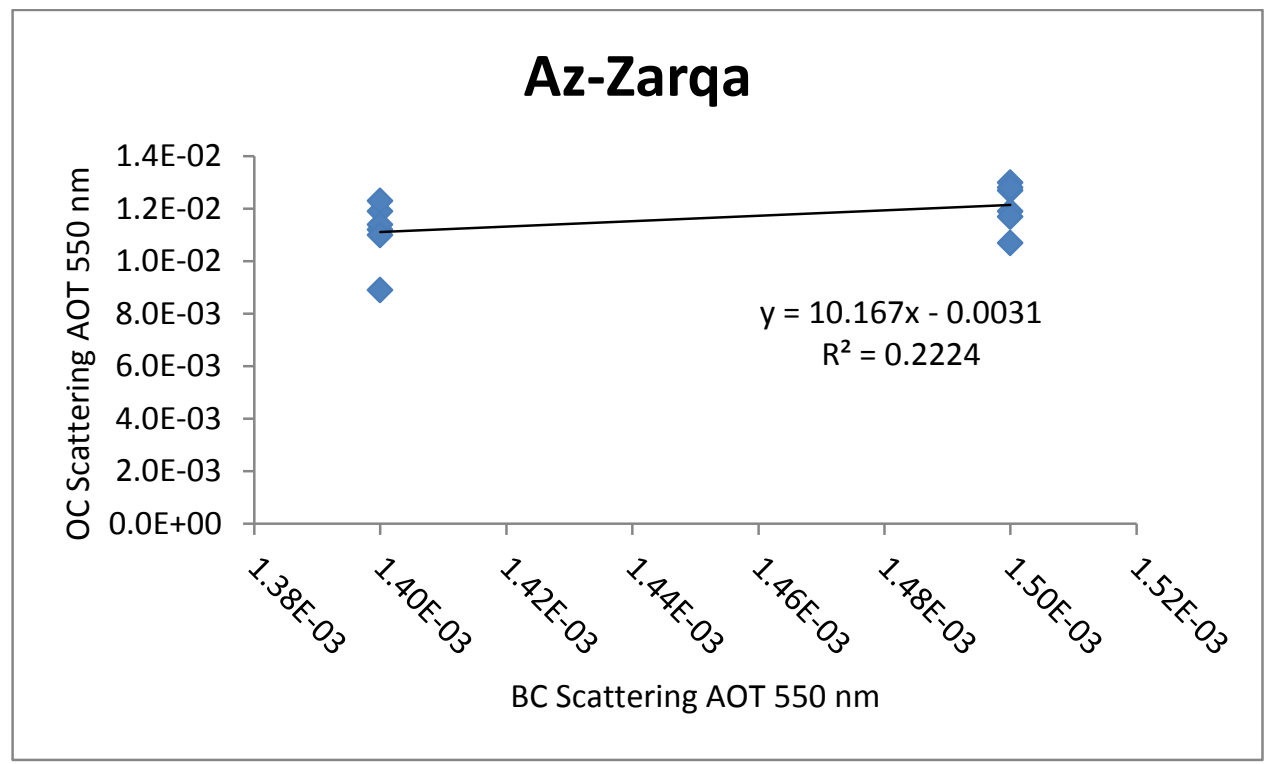

Fig. 20: Correlation between yearly average scattering value of black carbon and organic carbon in Az-Zarqa city.

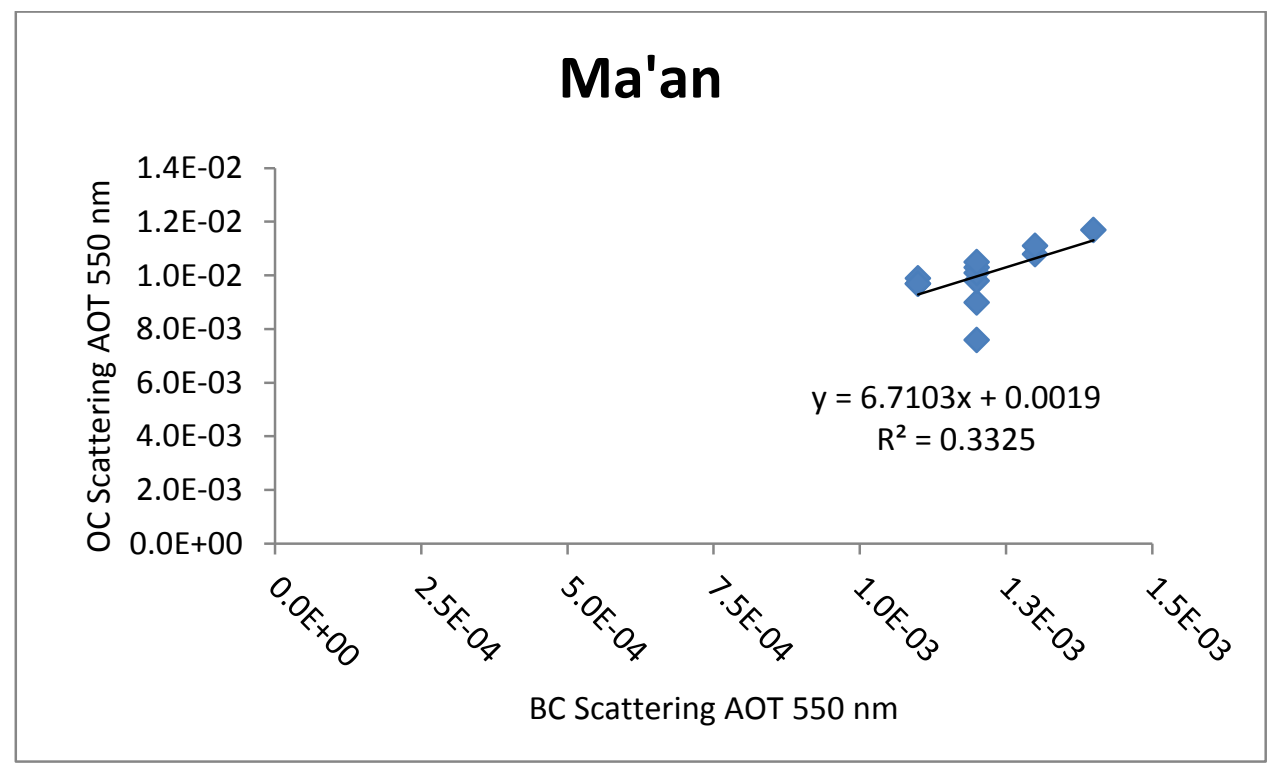

Fig. 21: Correlation between yearly average scattering value of black carbon and organic carbon in Amman city.

\section{CONCLUSION}

The amount of organic carbon at all sites is larger than black carbon and this leads to the belief that the sources of organic carbon in Jordan are more than the sources of black carbon. On the top of these sources is organic combustion.

Black carbon and organic carbon data keeps increasing as we go from south to north in Jordan. This increasing trend is because the south of Jordan is a desert with a low population density. While north of Jordan is a fertile plateau close to Syria from the north and Israel from the west. And since the prevailing direction of the winds in Jordan varies between the northwest and the southwest, the north of Jordan can be affected by more black and organic carbons from neighboring countries. 


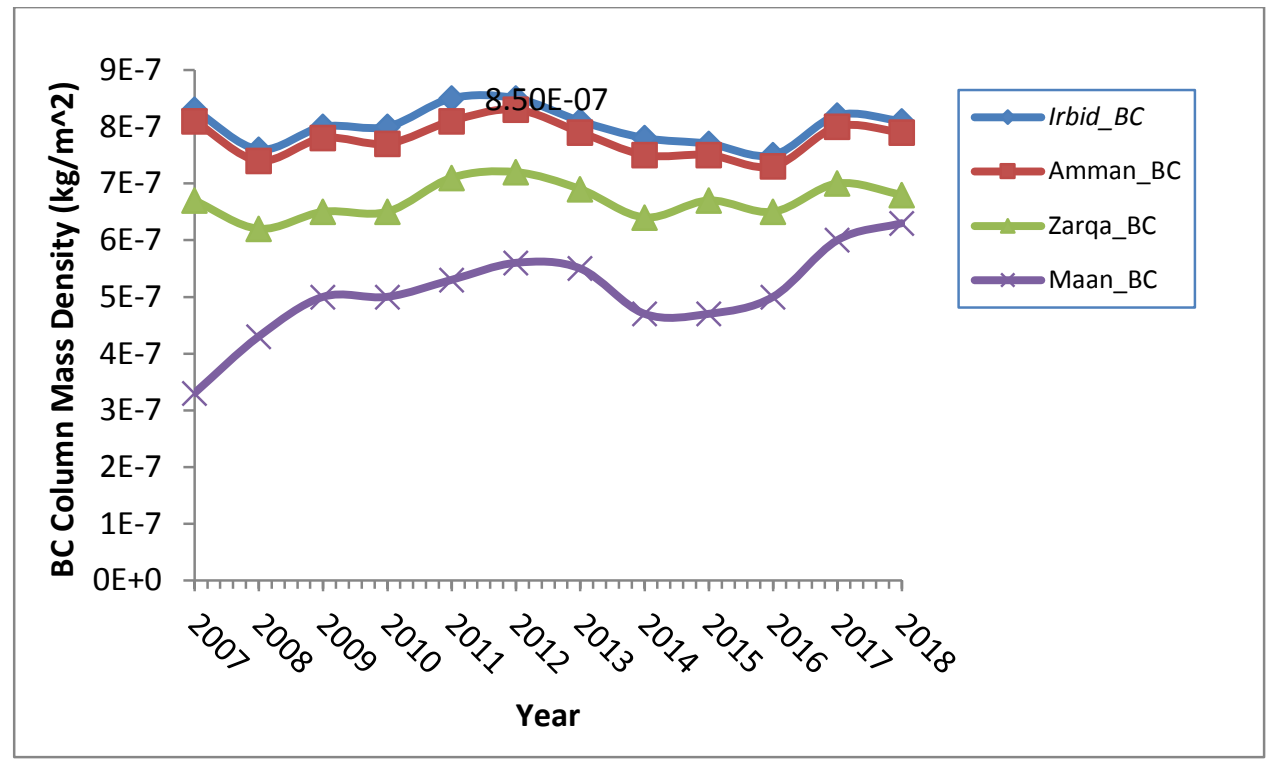

Fig. 22: Yearly average black carbon mass density during the period of 2007 to 2018 at Irbid, Amman, Az-Zarqa and Ma'an.

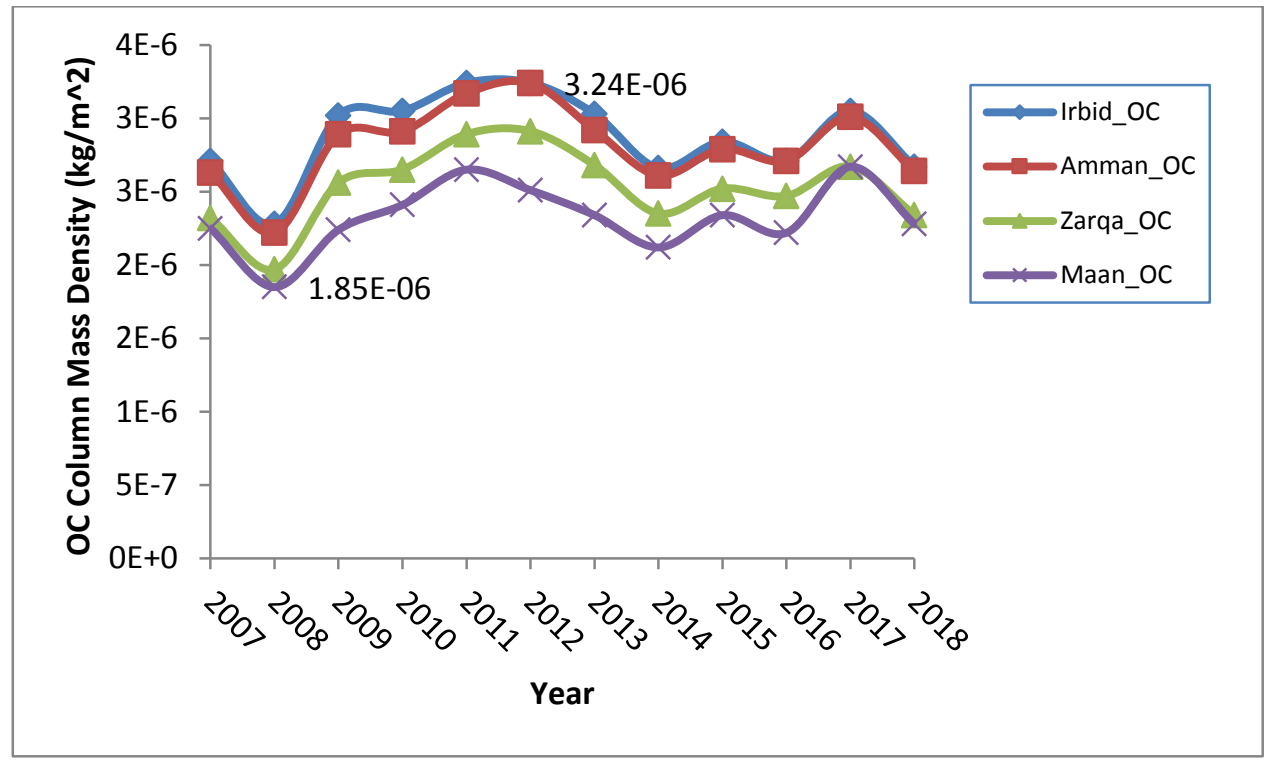

Fig. 23: Yearly average organic carbon mass density during the period of 2007 to 2018 at Irbid, Amman, Az-Zarqa and Ma'an.

Black carbon and organic carbon have maximum values in 2012 due to the Syrian civil war as Syria is adjacent to the northern Jordanian border. Air was polluted during the Syrian war as they used toxic weapons such as mortar bombs, artillery shells, barrel bombs, aircraft bombs, and missiles which have taken a toll on the environment and the population's health (Zwijnenburg \& Kristine 2015). Besides that more than 1.5 M Syrian refugees entered Jordan and they are not in camps but are instead living in urban or rural areas, predominantly in the northern and eastern parts of the country. The rapid population growth and the development of the industrial and service sectors combined with increased vehicle traffic increased ambient air pollution levels. Sulfur dioxide is problematic due to the high sulfur content of Jordanian oil, carbon monoxide, nitrogen oxides, and particulate matter, with extinctions increasing proportionately in relation to population size, which pose risks to public health. 
Black carbon and organic carbon kept increasing for the period of study (2007 to 2018), which leads to global warming and increasing temperature. This leads to the expectation that Middle East countries will be affected by increasing climate variability and extreme events such as droughts, loss of soil fertility and erosion, leaching of mineral fertilizers, and heat stress on animals. The energy demand also rises especially in summer due to an unexpected increase in temperature in countries that are used to living in mild weather conditions and do not need air-conditioning, such as Jordan. In addition, it is expected that climate change impacts hit water resources, which is the main issue in Middle East countries.

From extinction and scattering, we can calculate absorption which is the most important for global warming and increasing temperature.

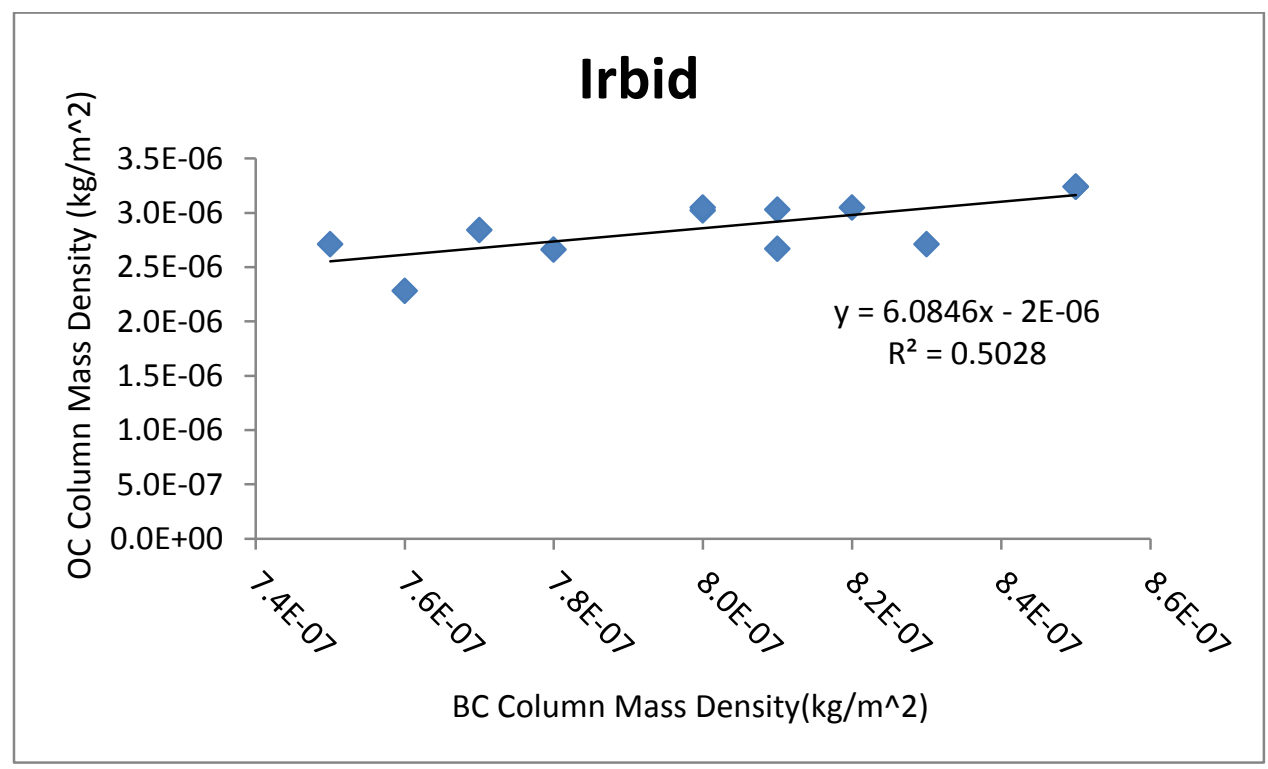

Fig. 24: Correlation between yearly average column mass density of black carbon and organic carbon in Irbid city.

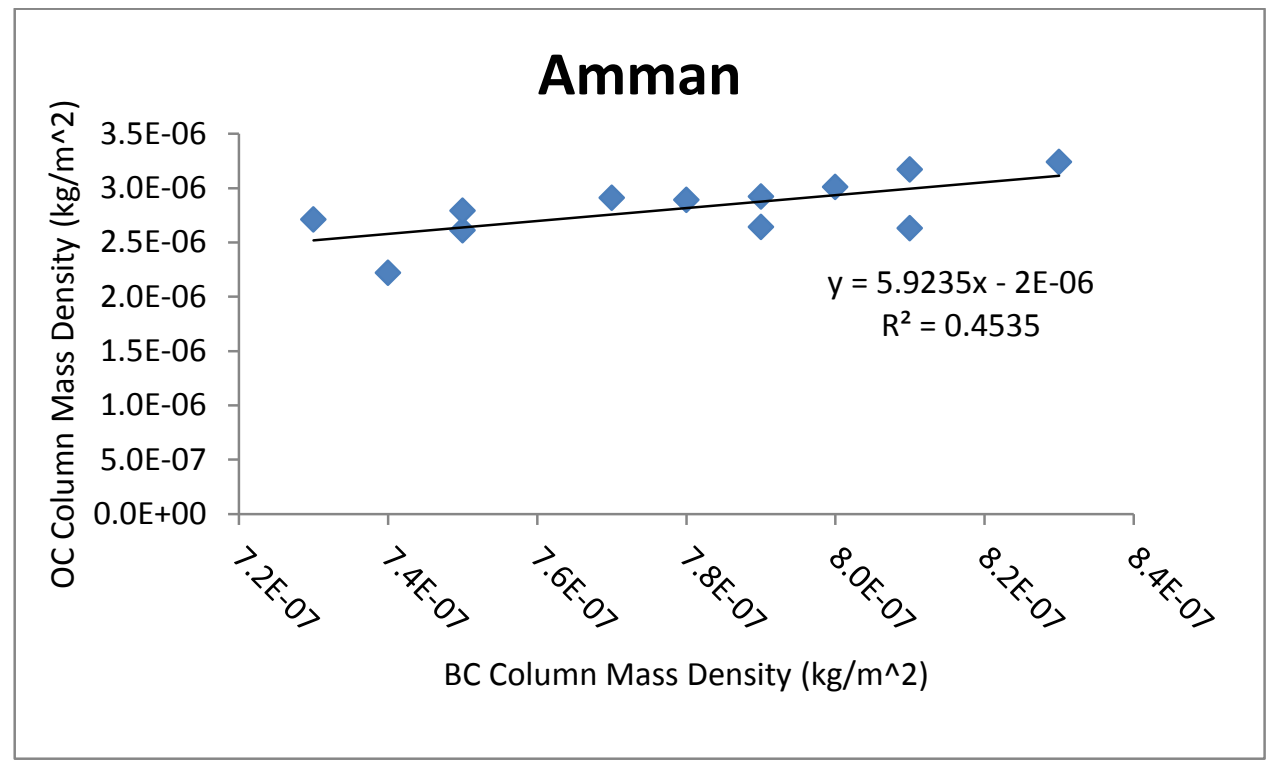

Fig. 25: Correlation between yearly average column mass density of black carbon and organic carbon in Amman city. 


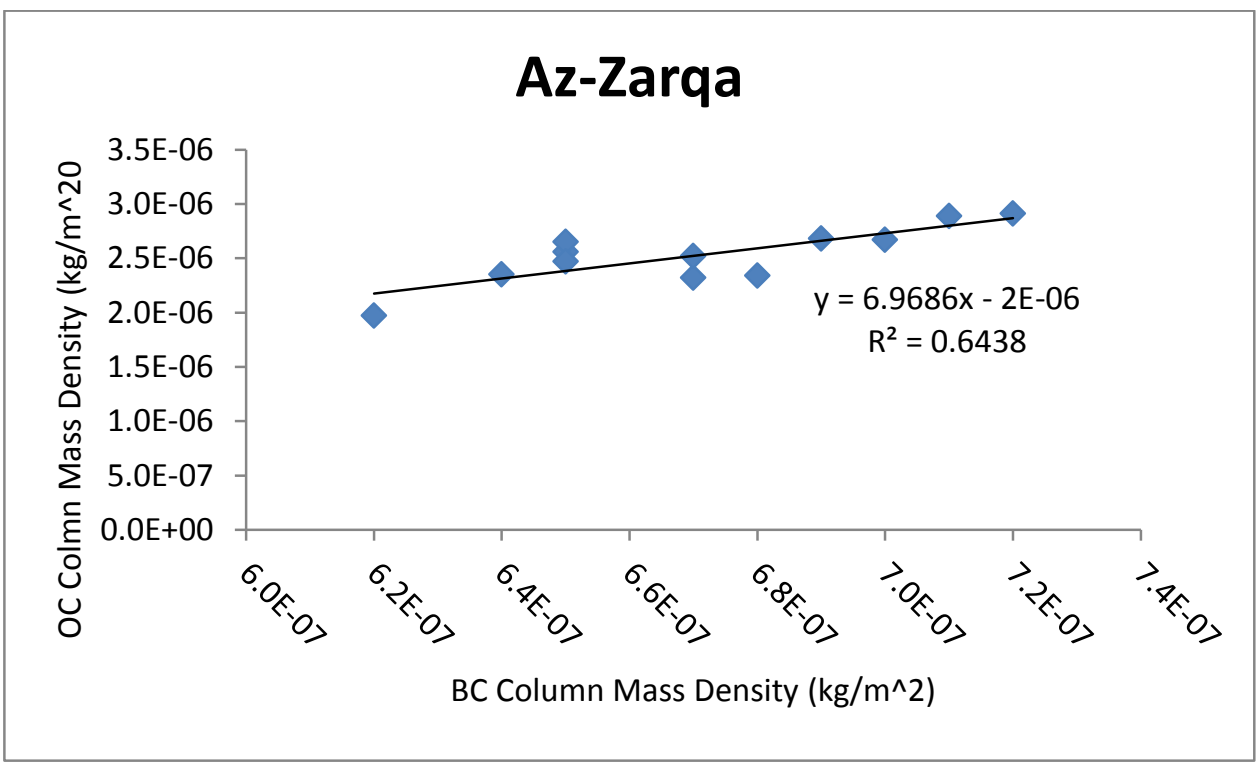

Fig. 26: Correlation between yearly average column mass density of black carbon and organic carbon in Az-Zarqa city.

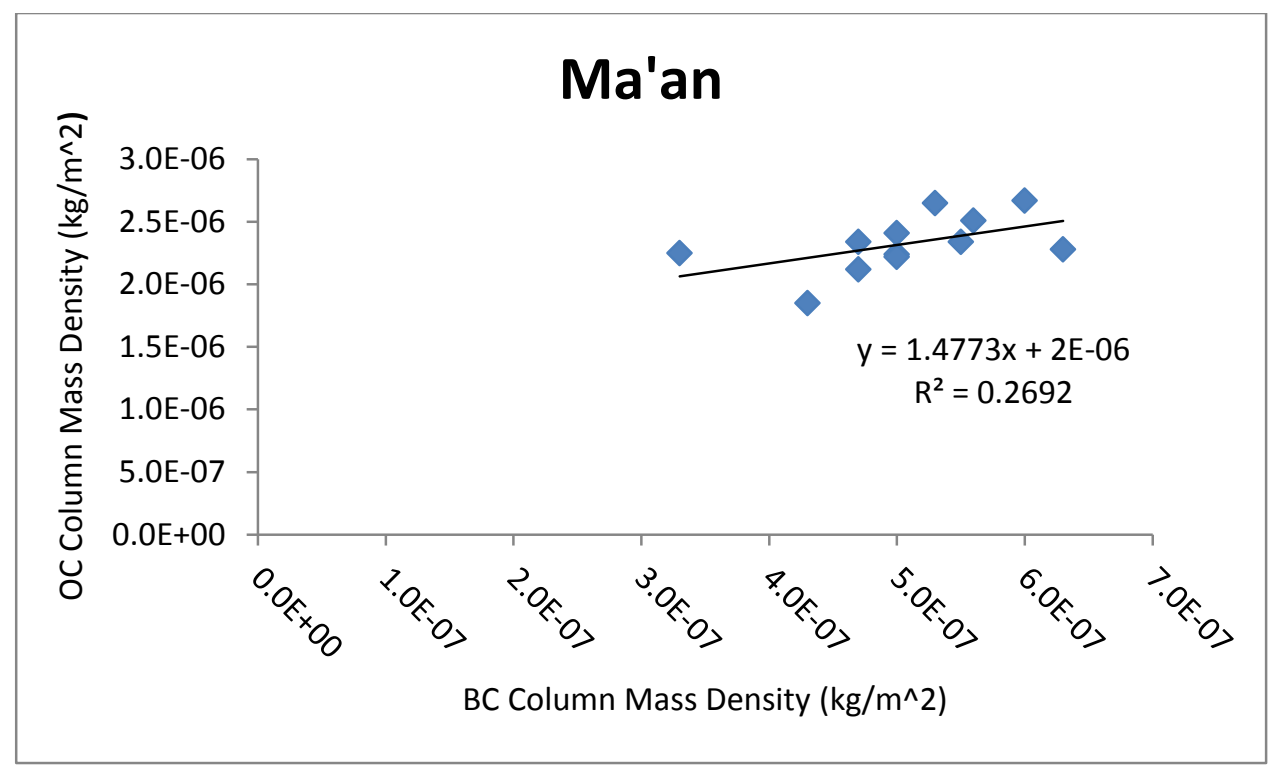

Fig. 27: Correlation between yearly average column mass density of black carbon and organic carbon in Irbid city.

\section{ACKNOWLEDGMENT}

Analyses and visualizations used in this paper were produced with the Giovanni online data system, developed and maintained by the NASA GES DISC.

\section{REFERENCES}

Acker, J.G. and Leptoukh, G. 2007. Online analysis enhances the use of NASA Earth science data. Eos. Trans. AGU, 88(2): 14 - 17.

Hamasha, K., Ababneh Z., Hamadneh H. and Hamasha K.H. 2015. Analysis of aerosol optical depth at Jordan during 2003-2012 using MODIS data. J. Nature Environ. Pollut. Technol., 14(1): 195-202

Hamasha, K. M., M. S., Almomani, M., Abu-Allaban, K.M. and Arnott, W.P .2010. Study of black carbon levels in city centers and industrial centers in Jordan. Jordan J. Phys., 3(1): 1-8.

Hamasha, K. 2010. Visibility degradation and light scattering/absorption due to aerosol particles in urban/suburban atmosphere of Irbid, Jordan. Jordan J. Phys., 3(2): 83 - 93.

Hamasha, K. and Arnott, W.P. 2010. Photoacoustic measurements of black carbon light absorption coefficients in Irbid city, Jordan. Environ. Monit. Assess. 166: 485-494.

Hime, N.J., Marks, G.B. and Cowie, C.T. 2018. A comparison of the health 


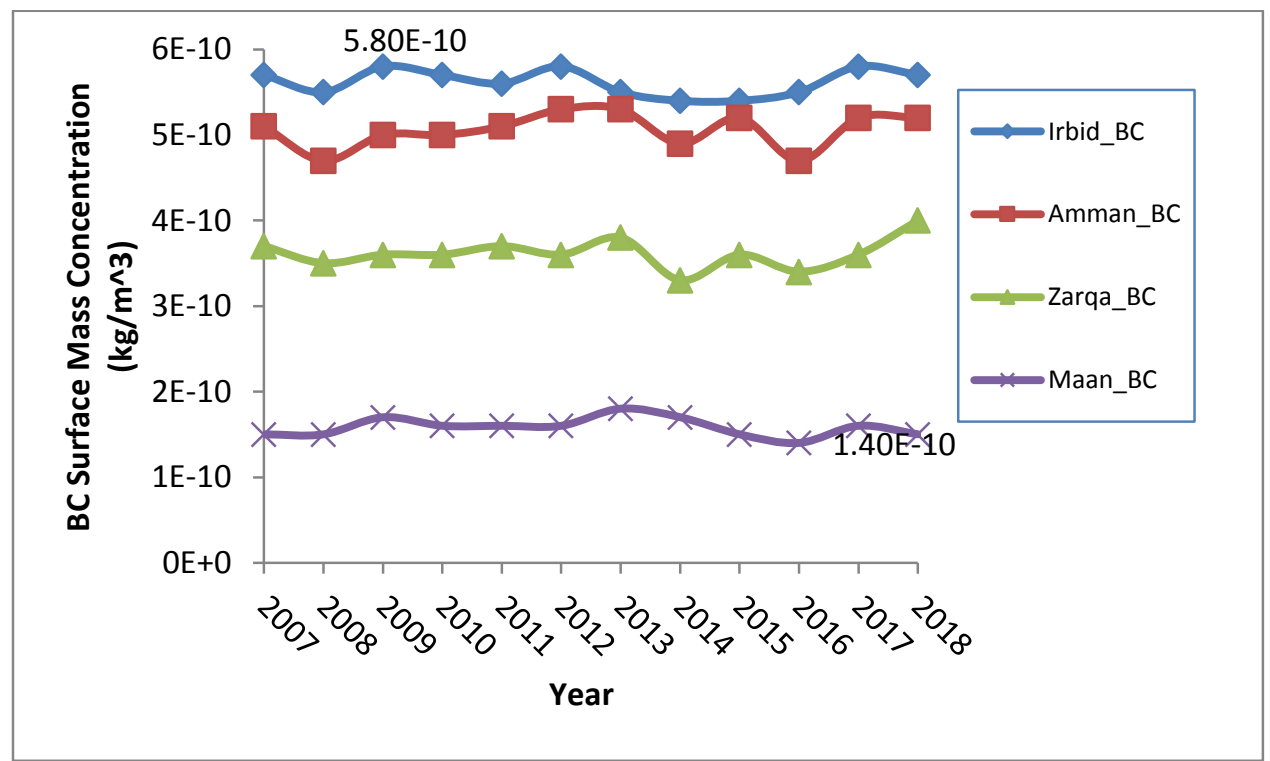

Fig. 28: Yearly average black carbon surface mass concentration during the period of 2007 to 2018 at Irbid, Amman, Az-Zarqa and Ma'an.

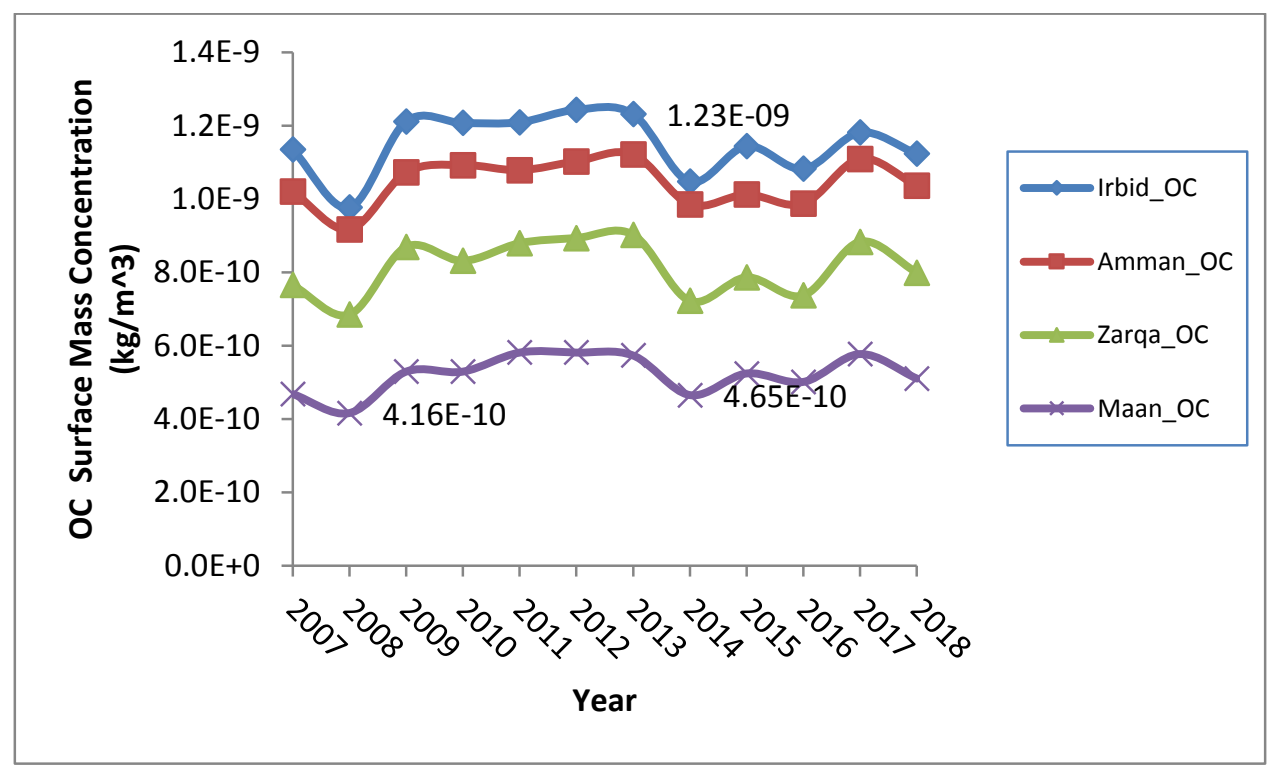

Fig. 29: Yearly average organic carbon surface mass concentration during the period of 2007 to 2018 at Irbid, Amman, Az-Zarqa and Ma'an. 


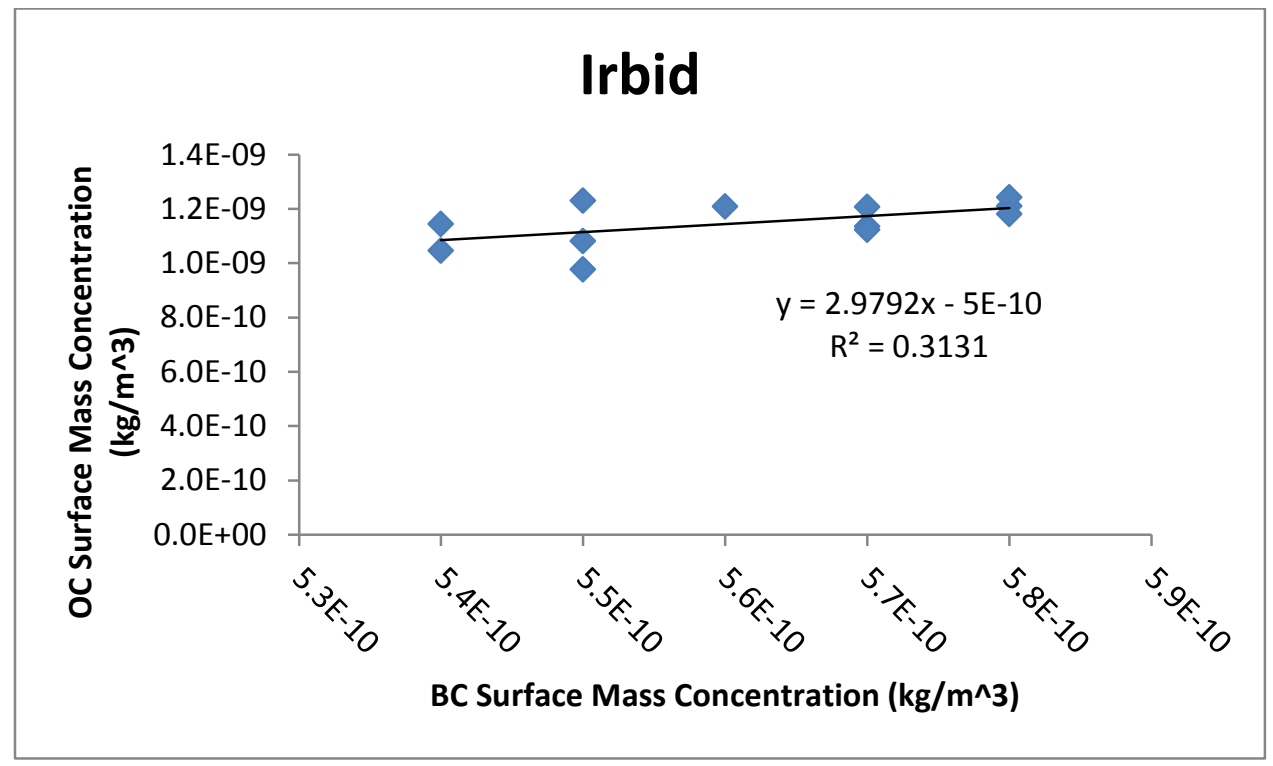

Fig. 30: Correlation between yearly average surface mass concentration of black carbon and organic carbon in Irbid city.

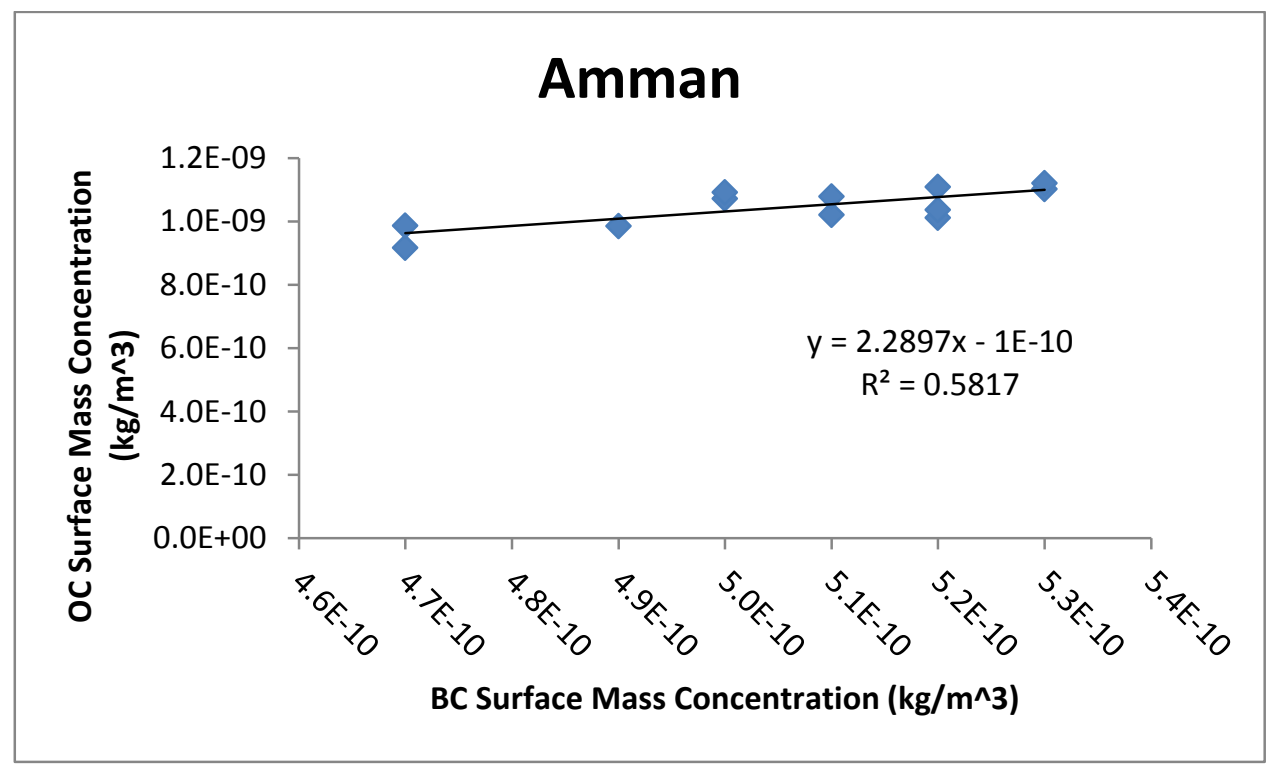

Fig. 31: Correlation between yearly average surface mass concentration of black carbon and organic carbon in Amman city.

effects of ambient particulate matter air pollution from five emission sources. Int. J. Environ. Res. Public Health., 15(6): 1206.

Hussein T., Abu Al-Ruz1 R., Petäjä T., Junninen H., Arafah D., Hämeri K. and Kulmala M. 2011. Local air pollution versus short-range transported dust episodes: a comparative study for submicron particle number concentration Aerosol Air Qual. Res., 11: 109-119.

Intergovernmental Panel on Climate Change (IPCC) 2018. Global warming of $1.5^{\circ} \mathrm{C}$ : an IPCC special report on the impacts of global warming of $1.5^{\circ} \mathrm{C}$ above pre-industrial levels and related global greenhouse gas emission pathways, in the context of strengthening the global response to the threat of climate change, sustainable development, and efforts to eradicate poverty. Intergovernmental Panel on Climate Change.
Liu Z., Lin Shi, C., Li, A. and Meyer, D. 2020. NASA Global satellite and model data products and services for tropical meteorology and climatology, Remote Sens., 12(17): 2821

Lung, C., Chen, S., Yang, C., Chen, Y., Chang, S., Tseng, W. and Liu S. 2016. Using atmospheric visibility to assess the effects of air pollution on hospital admissions for respiratory diseases. Aerosol Air Qual. Res., 16: 2237-2244.

McDonald, B.C., Goldstein, A.H. and Harley, R.A. 2015. Long-term trends in California mobile source emissions and ambient concentrations of black carbon and organic aerosol. Environ. Sci. Technol., 49(8): 5178-5188

MacKenzie, A.R., Langford, B., Pugh, T.A.M. and Robinson, N.H. 2011. 


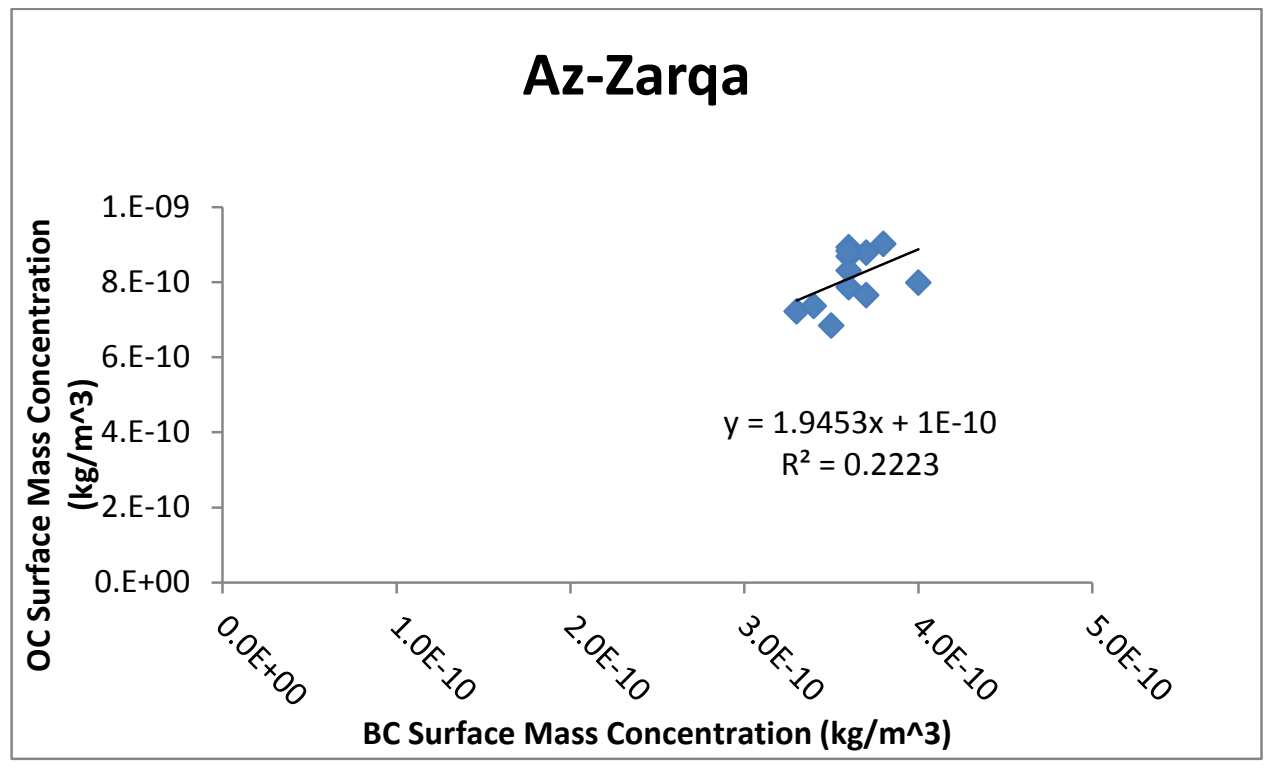

Fig. 32: Correlation between yearly average surface mass concentration of black carbon and organic carbon in Az-Zarqa city.

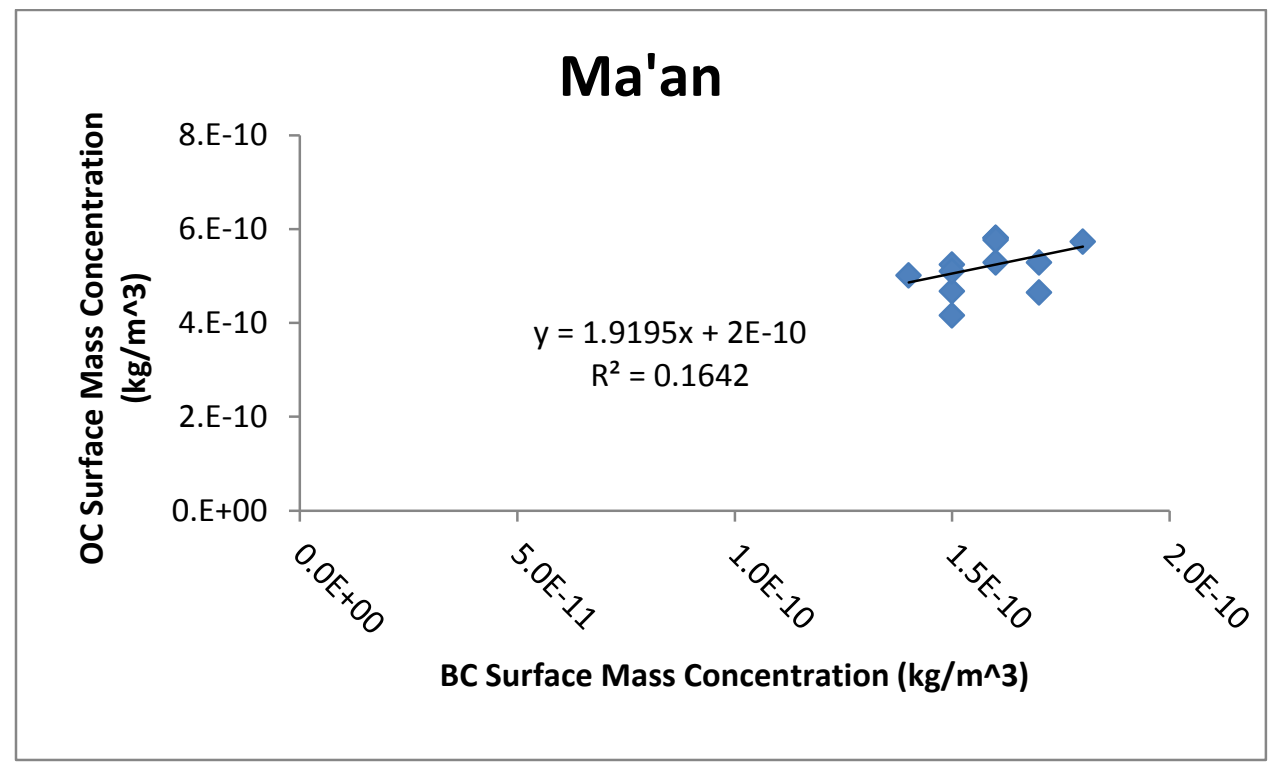

Fig. 33: Correlation between yearly average surface mass concentration of black carbon and organic carbon in Ma'an city.

The atmospheric chemistry of trace gases and particulate matter emitted by different land uses in Borneo. Philos. Trans. R. Soc. Biol Sci., 366(1582): 3177-3195.

Mok, J., Krotkov, N.A., and Arola, A. 2016. Impacts of brown carbon from biomass burning on surface UV and ozone photochemistry in the amazon basin. Sci. Rep. 6: 36940.

Myhre, G., Myhre, C.E.L., Samset, B.H. and Storelvmo, T. 2013. Aerosols and their relation to global climate and climate sensitivity. Nature Edu.
Knowl., 4(5):7

Zhanqing, L., Rosenfeld, D. and Fan, J. 2017. Aerosols and their Impact on Radiation, Clouds, Precipitation \& Severe Weather Events. Oxford Research Encyclopedia of Environmental Science, United States.

Zwijnenburg, W. and Kristine, P.T. 2015. Amidst the Debris. In: Weir, D. and Zeijden, V.D.W. (eds.). A desktop study on the environmental and public health impact of Syria's conflict. PAX, Syria, pp. 1-84. 